\title{
КОМПЛЕКСНАЯ ОЦЕНКА СОЦИАЛЬНО-ЭКОНОМИЧЕСКОЙ ВОВЛЕЧЕННОСТИ ГРАЖДАН СТАРШЕГО ПОКОЛЕНИЯ В РЕГИОНАЛЬНЫЙ СОЦИУМ НА ПРИМЕРЕ ТРУДОВОЙ АКТИВНОСТИ
}

\author{
Павлова Ирина Анатольевна 1,2 , \\ iapav@mail.ru \\ Недоспасова Ольга Павловна ${ }^{1,3}$, \\ olgaeconomy@mail.ru \\ Барышева Галина Анзельмовна 1 , \\ ganb@tpu.ru \\ 1 Национальный исследовательский Томский политехнический университет, \\ Россия, 634050, г. Томск, пр. Ленина, 30 \\ 2 Томский государственный университет систем управления и радиоэлектроники, \\ Россия, 634050, г. Томск, пр. Ленина, 40 \\ ${ }^{3}$ Национальный исследовательский Томский государственный университет, \\ Россия, 634050, г. Томск, пр. Ленина, 36
}

Павлова Ирина Анатольевна, кандидат экономических наук, доцент Школы инженерного предпринимательства Национального исследовательского Томского политехнического университета; доцент кафедры управления инновациями Томского государственного университета систем управления и радиоэлектроники.

Недоспасова Ольга Павловна, доктор экономических наук, профессор Школы инженерного предпринимательства Национального исследовательского Томского политехнического университета; профессор Института экономики и менеджмента Национального исследовательского Томского государственного университета.

Барышева Галина Анзельмовна, доктор экономических наук, профессор Школы инженерного предпринимательства Национального исследовательского Томского политехнического университета.

Актуальность. С возрастом у человека нарастает дефицит социально-экономических ролей, происходит сужение спектра при выборе достойных траекторий социально-экономической активности. В связи с этим актуальным становится исследование разнообразных траекторий вовлеченности старшего поколения в региональный социум. В первую очередь такие траектории связаны с трудовой активностью, которая реализуется через институты наемного труда, предпринимательства и в домашнем хозяйстве. Цель исследования: комплексный анализ социально-экономической активности граждан старшего поколения на примере основных траекторий их трудовой активности. Данная статья также призвана представить результаты оценки траекторий трудовой активности для лиц старшего возраста на различных этапах их жизненной траектории. Методы: дескриптивный статистический анализ на основе микроданных двух лонгитюдных обследований: «Российский мониторинг экономического положения и здоровья населения» Высшей школы экономики (RLMS-HSE); «Комплексное наблюдение условий жизни населения» (КОУЖ), проводимое Росстатом. Результаты анализа представлены в разрезе возрастных групn (50-54, 55-59, 60-64, 65-69, 70-74, 75-80, 80+) по трем траекториям: занятость по найму (полная и частичная); самозанятость и предпринимательство; домашний труд и личное подсобное хозяйство. Выводы: анализ показал широкое разнообразие траекторий вовлеченности граждан различных возрастных групn (в 
том числе за границами трудоспособного возраста) в трудовую активность, что в целом отражает их высокую адаптивность к социально-экономическим условиям РФ последних десятилетий.

Ключевые слова: Пожилые люди, старшее поколение, социально-экономическая активность, вовлеченность, трудовая активность, занятость, личное подсобное хозяйство, региональный социум, рынок труда.

\section{Введение}

Глобальный тренд роста продолжительности жизни породил системный кризис адаптации социальных институтов к новой возрастной структуре общества и обусловил необходимость гармонизации социально-экономического взаимодействия людей различных возрастных групп, актуализации привычного спектра факторов социально-экономического развития регионов, продления периода трудоспособности и повышения инициативной занятости человека за границами экономически активного возраста, социально-экономической активности людей старшего возраста как важнейших условий максимально длительного сохранения их автономии.

Под вовлеченностью пожилых людей в региональный социум в проекте понимается сочетание институциональных условий, социоэкономического статуса, физического, эмоционального, интеллектуального состояния человека, мотивирующее его к сохранению и (или) к повышению, с одной стороны, социально-экономической активности (включая рынок труда), а с другой стороны - личной автономии в пожилом возрасте. Под траекториями вовлеченности пожилых людей в социум в данном исследовании было решено понимать комбинации множества типичных (устойчивых) форм вовлеченности с учетом специфических условий их проявления.

Несмотря на принятие в 2016 г. национальной «Стратегии действий в интересах граждан старшего поколения в Российской Федерации до 2025 года» [1] и предложенной в ней градации граждан старшего поколения на три возрастные группы (60-64 года, 6580 лет и старше 80 лет), априори дифференцированных по потенциалу сохранения и продления социально-экономической активности за границами официального пенсионного возраста, в обществе сохраняется стереотипное представление о пожилых людях, главная проблема которых - низкая пенсия и недостаток внимания со стороны государства.

В настоящее время в России отсутствует общая концепция вовлеченности граждан старшего поколения в региональный социум, не создана методика измерения и оценивания эффективности различных траекторий их вовлеченности с точки зрения интересов личности, работодателя и общества в целом. По этой причине операционализация данного процесса в системе количественных и качественных показателей, в том числе в динамике, представляет собой определенные трудности.

Актуальность исследования определяется, с одной стороны, безусловным признанием непреходящей ценности пожилых людей, их роли «социального клея» современного общества, необходимостью повышения их востребованности в динамике современной жизни. С другой - актуальность выбранного ракурса обусловлена нарастающим разрывом в уровне и качестве жизни старшего поколения как важнейших характеристик личной автономии в сравнении с аналогичными параметрами для населения трудоспособного возраста. Как известно, средний уровень пенсий в РФ ощутимо ниже среднего уровня заработной платы (в Томской области - в 2,5 раза).

Актуальность проблемы усиливается тем, что с возрастом у человека нарастает дефицит социально-экономических ролей, происходит сужение спектра при выборе достойных траекторий социально-экономической активности. При этом подавляющее число 
пожилых людей проживают (и, очевидно, будут проживать в дальнейшем) преимущественно не в мегаполисах, а на периферии, в малых и средних городах, районных центрах и удаленных (труднодоступных) поселениях, где социально значимые паттерны активности людей старшего поколения обычно выпадают из поля широкого публичного обсуждения, уступая место патерналистской традиции помощи и заботы о пожилых людях как социально незащищенных и преимущественно пассивных слоях населения. Авторы статьи убеждены, что научная значимость решения проблемы состоит в преодолении противоречий между высоким потенциалом социально-экономической активности людей старшего поколения в различных возрастных группах и существующими социокультурными и институциональными ограничениями его использования, легитимными способами обеспечения и повышения их личной автономии.

Масштабность научной задачи по выявлению, обоснованию и измерению эффективности вовлеченности пожилых людей в региональный социум с точки зрения интересов индивида, работодателя и общества в целом определяется глобальными демографическими изменениями и существенным обострением ресурсных ограничений современного общества. При реализации такой значимой научной задачи следует делать основной акцент не на «вовлечение» граждан старшего поколения, а на их «вовлеченность» - активную позицию субъектов, их социально и экономически значимую (с точки зрения личности, работодателя и общества) деятельность в региональном социуме.

Целью данной работы является комплексный анализ социально-экономической активности граждан старшего поколения на примере основных траекторий их трудовой активности. Данная статья также призвана представить результаты оценки траекторий трудовой активности для лиц старшего возраста на различных этапах их жизненной траектории.

\section{Обзор литературы}

Активное долголетие - одна из наиболее востребованных научных концепций, находящаяся на стыке множества современных социальных наук и в рамках которой смещаются акценты в оценке роли пожилых людей в современном обществе с пассивных получателей социальной помощи к активным, независимым участникам социальной деятельности и трудовых отношений. Еще в 1961 г. в работе [2] появилась совершенно новая точка зрения на процесс старения. Авторы критиковали доминирующую на тот момент концепцию исключения старшего поколения из социально-экономической жизни. Однако данный подход в то время не получил широкого распространения в науке. Одновременно возникла и начала активно развиваться теория человеческого капитала. Для целей данного исследования особую ценность представляют взгляды тех ее сторонников, которые погружены в исследование человеческого капитала как особого вида нематериального богатства индивида и общества, занимаются экономической оценкой отдачи от его использования и множественными социально-экономическими экстерналиями. С точки зрения экономической теории способности индивида к обучению сравнимы с любыми другими экономическими ресурсами и факторами производства [3]. А при эффективном использования любого ресурса получаемые результаты будут значимы на уровне индивида, отдельной организации и общества в целом [4]. Теория человеческого капитала предполагает инвестирование в развитие человеческих ресурсов, динамика которого может зависеть от множества факторов: особенностей национальной экономики, роли государства, специфики законодательства и т. д. [5]. Предполагается, что качество человеческого капитала вполне заслуженно обосновывает связь между собственно инвестициями в его развитие и производительностью национальной экономики [6]. 
Новый виток интереса к концепции активного долголетия возник на волне глобального демографического кризиса в начале $1990-$ х гг., когда устойчиво начала расти доля лиц третьего (60+) и особенно четвертого (75+) возраста, в то время как численность трудоспособного населения и детей неуклонно сокращалась, что привело к значительному увеличению нагрузки на социальные фонды и систему социального обслуживания. В стратегическом документе ЕС «Европа для всех возрастов» обозначены четыре угрозы демографических изменений: увеличение спроса на услуги социального обслуживания, рост расходов на пенсионное обеспечение и социальные гарантии, рост потребностей лиц старшего возраста, неравенство в доступе к ресурсам и разнообразие социальных рисков для старшего поколения [7].

Концепция активного долголетия стала официальным приоритетом в поддержке и проведении исследований старения населения Всемирной организации здравоохранения. Эксперты ВОЗ определяют активное долголетие как процесс оптимизации возможностей для здоровой, активной и безопасной жизни в целях повышения качества жизни населения в процессе старения.

Мультидисциплинарная концепция активного долголетия рассматривает старение как многоаспектный феномен, охватывающий всю жизнь человека [8]. Особое внимание авторы также уделяют механизмам длительного социального обслуживания (long-term care) и психологическому состоянию пожилых людей $[9,10]$, вопросам стимулирования социальной активности самих пожилых людей (волонтерство, благотворительность, социальное предпринимательство силами пожилых людей или в их интересах) [11]. В рамках совершенствования государственной социальной политики интерес представляет анализ динамики официальной границы пенсионного возраста и смещения границ трудоспособности в разных странах [12].

В Европейском Союзе концепция активного долголетия приобретает особое значение в силу высокой степени взаимозависимости государств ЕС и тенденции унификации нормативно-правовой базы в отношении граждан старшего возраста. В целях мониторинга основных сфер реализации активного долголетия в ЕС разработаны базовые принципы расчета индекса активного долголетия (Active Ageing Index) [13], предварительные оценки которого сделаны и для России [14]. Данный индекс охватывает разнообразные сферы вовлеченности лиц старшего поколения в региональный социум, причем занятости в разных возрастных группах посвящен отдельный субиндекс. В этом контексте важно оценивать влияние социально-экономического статуса человека на его здоровье в пожилом возрасте [15].

Научные исследования в области социальной политики развитых стран отражают четкую тенденцию сдвига парадигмы с оказания помощи пожилым людям на эффективное использование социального и трудового потенциала человека старшего возраста. Если в первой половине XX в. насущной необходимостью было обеспечение пожилых людей минимальными средствами для существования, то сегодня наиболее актуальными задачами являются мотивация и социальные технологии к продлению активной жизни человека в продуктивном режиме, формирование установок на продолжение активной социально-экономической деятельности за границами официального пенсионного возраста, после выхода человека на пенсию - преодоление дискриминационных практик в отношении граждан старшего возраста (эйджизма) [16].

В последнее время заметным явлением в обществе становится разочарование в традиционных «опекающих», «патерналистских» стратегиях в отношении пожилых людей, которые западные специалисты прямо называют «инвалидизирующими». Людям старшего возраста, как и другим, объективно имеющим особые потребности 
(международный термин «special needs», не тождественный ограниченным возможностям), обычно приписывается роль пассивных получателей и потребителей социальных благ и услуг, они рассматриваются как субъекты, нуждающиеся в предоставлении им особых форм помощи и защиты. Такая коннотация социальной политики в отношении пожилых людей ведет к их дискриминации, сводит всю гамму социально-экономических ролей старшего поколения преимущественно к потребительской.

Модели социальной политики в современной России присущ смешанный характер. Она в значительной мере представляет собой заимствование и апробацию практик и опыта зарубежных государств, прежде всего в части инвестиций в социальное развитие индивида [17]. Одной из плодотворных идей для увеличения вариативности направлений в реализации социальной политики государства может стать идея пересмотра формулы: детство - учеба, взрослость - работа, старость - покой, когда все три вида деятельности должны быть обеспечены в любом возрасте [18].

Участие старшего поколения в трудовых отношениях представляет собой важный аспект исследования не только с точки зрения экономики, но также социологии и психологии. Экономически стареющее население является существенным трудовым ресурсом, зачастую недооцененным. Экономически активные представители старшего поколения обладают ценными профессиональными знаниями, но также имеют и свои особые потребности, мотивацию к вовлеченности в трудовую активность [19]. Период перехода от полной занятости в трудоспособном возрасте к занятости в пенсионном возрасте получил название bridge employment. Данный термин предполагает многообразие траекторий и мотиваций к трудовой активности в старшем возрасте, включая продолжение трудовых отношений с прежним работодателем в режиме полной или частичной занятости; постоянную или временную занятость на новом месте работы; самозанятость [20]. Причем период таких трудовых отношений рассматривается и анализируется в динамике - не просто с наступлением пенсионного возраста, а с предпенсионного возраста 50+ [21]. Само участие на рынке труда для этого возрастного периода исследуется на предмет не только удовлетворенности самой работой и связанного с ней дохода, но и удовлетворенности социализацией (социальные связи/контакты), которую такая занятость обеспечивает [22].

Одним из новых трендов для российского общества является повышение ответственности как государства, так и самого человека за благополучие на всех этапах жизненной траектории, в том числе в пожилом возрасте. В программе социально-экономического развития России «Стратегия-2020: Новая модель роста - новая социальная политика» [23] признается, что рост благосостояния граждан невозможен без экономического роста, в основе которого прежде всего лежит его качественная трансформация. Должна быть создана соответствующая материально, социально и психологически комфортная среда с широким привлечением к реализации проектов государственных, коммерческих, общественных добровольческих (некоммерческих) структур, меняющих жизненный курс в стареющем обществе в направлении его большей вариативности, предполагающей смену стереотипной временной последовательности ролей и видов деятельности, строго привязанных к определенному отрезку жизненного пути.

\section{Алгоритм комплексной оценки социально-экономической активности граждан старшего поколения в региональном социуме}

Вовлеченность пожилых людей в региональный социум представляет собой двусторонний процесс, инициаторами которого в равной степени могут быть как сами представители старшего поколения, так и их близкие, родные, друзья, коллеги по работе, работодатели (прежние и нынешние), люди со схожими интересами и потребностями, 
представители местного сообщества и органов власти различного уровня, формальных и неформальных союзов и организаций.

Анализ лучших мировых и отечественных практик вовлеченности граждан старшего поколения в социум показывает наличие множества вариантов формирования соответствующих траекторий, которые отличаются не только в зависимости от социального и экономического статуса личности и условий жизни человека, но и институциональных рамок, степени государственной и общественной активности в формировании данных траекторий, сочетание которых предопределяет их персонифицированный выбор.

Систематизация дифференцированных траекторий вовлеченности пожилых людей может быть реализована на основе ресурсного подхода, согласно которому возможна их следующая группировка и соответствующий подход к оценке:

1. Ресурсы пожилых людей как производителей оцениваются через участие на рынке труда и в домашнем хозяйстве в рамках траекторий: а) трудовая активность в качестве наемного сотрудника; б) самозанятость и предпринимательство; в) занятость в личном подсобном хозяйстве.

2. Ресурсы пожилых людей как потребителей оцениваются по разным направлениям их затрат на приобретение товаров и услуг в краткосрочной и долгосрочной перспективе, в том числе специализированных высокотехнологичных товаров, а также по спросу на новые товары (способствующего созданию и развитию новых рынков): а) текущее потребление; б) приобретение товаров длительного пользования и образовательные услуги; в) создание спроса на новые и высокотехнологичные товары; г) создание спроса на специализированные сервисы консультационных услуг (социальные, юридические, эмоционально-психологическая поддержка и пр.).

3. Ресурсы пожилых людей, формирующих сети поддержки разных поколений предполагают их оценку через социальные связи в рамках ближнего и дальнего круга взаимодействий, т. е. в рамках межпоколенческих сетей поддержки, и включают: а) помощь и взаимодействие с младшими; б) помощь и взаимодействие с лицами еще более старшего поколения (представителями четвертого возраста); в) помощь и взаимодействие с людьми своего (примерно своего) возраста/поколения.

4. Социальные и культурно-политические ресурсы старшего поколения рассматриваются как значимые взаимодействия в рамках регионального социума по следующим траекториям: а) волонтерская и добровольческая деятельность; б) общественно значимая деятельность по месту жительства, в своем районе и на благо своего сообщества (community development); в) участие в политической жизни; г) вовлеченность в общественно-культурную жизнь.

Для оценки социально-экономической активности представителей старшего поколения на различных этапах жизненной траектории целесообразны разработка (в рамках указанных выше направлений) системы специальных индикаторов и оценивание активности граждан разных возрастных групп с шагом в пять лет, начиная с предпенсионного возраста $(50-54,55-59,60-64,65-69,70-74,75-79,80+)$. Включение в анализ предпенсионного возраста позволит определить т. н. «фазовый переход» - переломный момент в социально-экономической активности по конкретной траектории от скорее активной позиции к неактивной. В силу существенных различий в РФ показателей продолжительности жизни для женщин и мужчин рекомендуется проводить данную оценку не только в разрезе разных возрастных групп, но и по половому признаку.

В качестве открытых источников данных для этой цели были выбраны следующие исследования: 
- лонгитюдное обследование домохозяйств «Российский мониторинг экономического положения и здоровья населения» Высшей школы экономики (RLMS-HSE);

- «Комплексное наблюдение условий жизни населения» (КОУЖ), проводимое Росстатом.

Данные источники являются лонгитюдными, открытыми и позволяют использовать микроданные для их сортировки по половозрастному признаку, а также в разрезе российских регионов. B RLMS-HSE доступны данные по ряду российских регионов, но они репрезентативны только для России в целом. На основе КОУЖ возможно проводить анализ по всем российским регионам (при условии наличия достаточного количества ответов по соответствующему вопросу). В нем также возможно использование как данных индивидуального обследования, так и результатов обследования домохозяйств.

\section{Траектории вовлеченности пожилых людей в региональный социум через трудовую активность}

Устойчивым трендом последних лет является повышение запроса и расширения спектра практик по активному участию пожилых людей в основных социально-экономических, политических, культурных и других общественно-значимых процессах, происходящих в местном сообществе. Именно поэтому различные виды и формы активности пожилых людей в региональном социуме все чаще рассматриваются не в традиционной парадигме вовлечения в соответствующие процессы (пожилые как объекты активности), но и с позиций вовлеченности (пожилые как субъекты активности). В таких условиях важно понимать развитие траекторий вовлеченности пожилых людей в региональный социум и корректно оценивать их эффективность. Понятие эффективности в данном случае тесным образом связано с ракурсом оценки, приоритезации в ней точки зрения индивида, других субъектов (в частности, работодателей) и (или) общества в целом.

Поскольку каждый пятый гражданин РФ, находящийся в возрасте старше трудоспособного, продолжает трудиться, значительная часть траекторий вовлеченности пожилых людей в региональный социум проходит через рынок труда. Согласно имеющимся агрегированным данным Росстата, представленным в «Комплексном наблюдении условий жизни населения» [24], удовлетворены заработком менее половины пожилых людей, продолжающих работать. При этом интересна повышательная динамика такой удовлетворенности по мере увеличения возраста респондентов. Отметим высокие оценки пожилыми людьми надежности своей работы (в сравнении с более молодыми респондентами), а также дифференциацию ответов в этом направлении у городских и сельских жителей, а также у мужчин и женщин. Дополнительными гранями для оценки эффективности трудовой траектории вовлечений пожилых людей в социум следует признать субъективные оценки их удовлетворенности выполняемыми обязанностями, режимом работы, условиями труда, воздействия вредных производственных факторов, неудобств на работе (холод, сырость и др.), безопасности работы в целом, расстояния до рабочего места, морального удовлетворения (в том числе в его соотношении с материальной заинтересованностью). Для анализа эффективности трудовых траекторий вовлеченности пожилых людей в социум с позиций работодателя и общества в целом заслуживает внимания данные о том, что лишь у половины респондентов КОУЖ-2018 основная работа полностью соответствует полученной ими специальности. При этом примерно такая же часть опрошенных заявила о наличии у них навыков для выполнения более сложной работы, чем та, которую они имеют сейчас.

В целом для трудовой активности можно выделить три магистральных направления оценивания - три трудовые траектории: 
- траектория «Занятость по найму», которая включает в себя труд по найму (как полная, так и частичная занятость);

- траектория «Самозанятость и предпринимательство»;

- траектория «Домашний труд и личное подсобное хозяйство»; отметим, что данная траектория может генерировать не только индивидуальную, но и общественную экономическую ценность, которая не учитывается в ВВП страны, но является для части домохозяйств весьма важным источником дохода.

Прежде чем перейти к детальному описанию каждой из названых траекторий, приведем результаты обобщенных оценок респондентами различного возраста динамики материального положения своей семьи и удовлетворенности его текущим уровнем по данным за 2014, 2016 и 2018 гг. В 2014 г. во всех возрастных группах явно превалируют оценки типа «осталось без изменения»: минимум таких ответов - у самых молодых респондентов (50-54 года), максимум - более $65 \%$ - у граждан 75 лет и старше. Причем если у относительно молодых респондентов (50-45 и 55-59 лет) количество ответов «немного улучшилось» лишь незначительно превышало число респондентов, заявивших о том, что материальное положение их семей «немного ухудшилось», то в последующих возрастных группах (с возрастом в диапазоне от 60 до 79 лет) преобладали более негативные оценки. Исключением стали самые старшие респонденты, которые высказались о динамике материального положения своей семьи весьма оптимистично.

В 2016 г. аналогичные опросы дали несколько другие результаты. При этом так же, как и в 2014 г., наиболее часто респонденты отмечали, что материальное положение их семьи осталось без изменений: от 53,6 \% (минимум - у граждан 50-54 лет) до 67,1 \% (максимум - у граждан 80 лет и старше). При этом доля сказавших, что материальное положение «немного ухудшилось» ощутимо превышает оценки типа «немного улучшилось» во всех возрастных группах, а в совокупности с весьма заметной долей оценок типа «значительно ухудшилось» (особенно у граждан 70-74 лет на 14,1 \%) позволяет утверждать о негативной динамике в субъективном представлении граждан о своем материальном положении.

В 2018 г. ситуация во многом напоминает 2016 г. (рис. 1). По-прежнему наиболее распространённой оценкой для динамики материального положения за год для всех респондентов были ответы типа «осталось без изменений» (минимум - 55,5 \% для граждан 55-59 лет, максимум - 67,8 \% для граждан 80 лет и старше). При этом доля ответов «немного ухудшилось» (максимальное значение 24,5 \% у граждан 65-69 лет) значительно превышает ответы типа «немного улучшилось» (максимальное - 13,2 \% у граждан 5054 лет). А в совокупности с оценками «значительно ухудшилось» (максимум - 14,1 \% у граждан 70-74 лет) отражает весьма тревожное представление граждан о динамике материального положения своей семьи.

На фоне уже сделанных выводов анализ ответов респондентов различных возрастных групп об удовлетворенности материальным положением семьи за год выглядит весьма ожидаемым. В 2014 г. преобладающим ответом респондентов всех возрастных групп (за исключением самых старших) был «не совсем удовлетворены» На долю ответивших таким образом пришлось 37,5 \% граждан 65-69 лет (максимум) и 31,2 \% граждан 75-79 лет (минимум). Обращает на себя внимание также весьма высокая доля ответов «совсем не удовлетворены» максимум - 27,5 \% в возрасте 50-54 лет, минимум - 17,8 \% в возрасте 75-79 лет. Эти оценки, рассмотренные в совокупности, дают весьма тревожную характеристику общего настроения граждан. Исключением в этих оценках являются граждане 80 лет и старше. В этой возрастной группе преобладают оценки «скорее удовлетворены» $(54,2 \%)$, что в совокупности с оценками «полностью удовлетворены» $(11,3$ 
\%) говорят о весьма высоком субъективном уровне материального благополучия и соответствующем оптимизме.

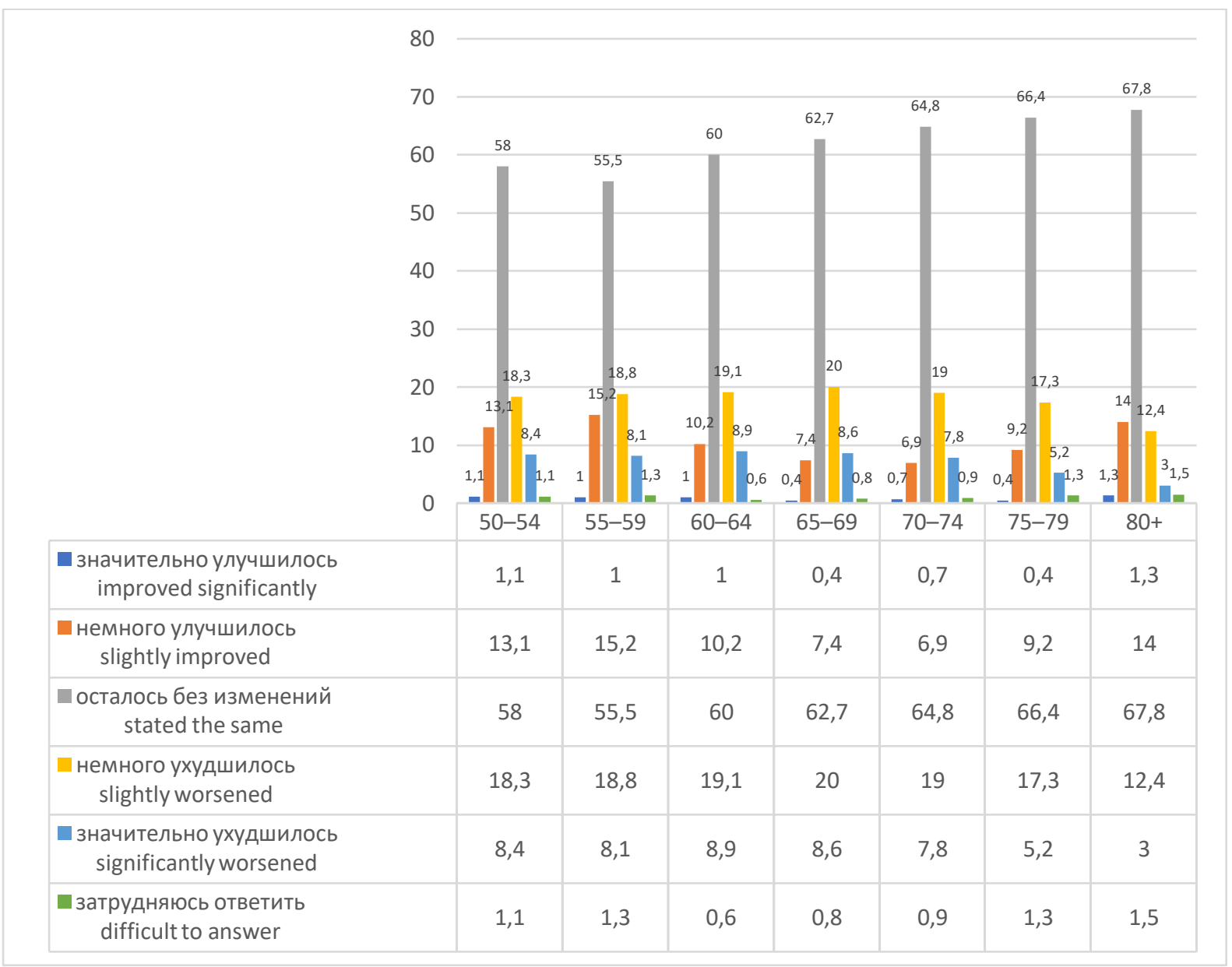

Puc. 1. Структура ответов респондентов различных возрастных групп о динамике материального положения семьи за год в 2018 г. (\%)

Fig. 1. Structure of the answers of respondents of different age groups about the dynamics of the financial situation of the family for the year in 2018 (\%)

В 2016 г. аналогичные оценки выглядят схожим образом. Оптимизм о своём материальном положении также был характерен лишь для самых старших респондентов, однако и здесь уменьшилась доля тех, кто сказал о том, что полностью удовлетворён своим материальным положением (только 8,9 \% вместо 11,3 \% в 2014 г.), а доля «скорее удовлетворённых, чем нет» сократилась с 45,2 \% до 39,3\%. Практически в каждой возрастной группе в 2016 г. по сравнению с 2014 г. снизилась доля граждан, сказавших, что они «скорее удовлетворены, чем нет» своим материальным положением (от 17,9\% в возрасте 50-54 лет до 26,9 \% в возрасте 75-79 лет), при этом возросла доля ответов типа «не совсем удовлетворены» и, что особенно тревожно, число ответивших «совсем не удовлетворены» (каждый пятый - в возрасте 75-79 лет, каждый четвертый - в возрасте 55-74 лет и каждый третий - в возрасте 50-54 лет).

Анализ ответов респондентов различных возрастных групп об удовлетворенности материальным положением семьи в 2018 г. (рис. 2) не меняет выявленной ранее тенденции. Здесь, как и в прежние годы, максимально оптимистично оценивают свое 
материальное положение лишь самые старшие респонденты, однако их оптимизм продолжает снижаться: на фоне сохранения доля ответивших «совсем не удовлетворены» совсем немного увеличивается доля тех, кто отмечает, что «не совсем удовлетворён своим материальным положением» и снижается доля тех, кто «скорее удовлетворён, чем нет». В других возрастных группах по-прежнему преимущественным ответом является «не совсем удовлетворены» (в диапазоне от 31 до 37 \%). При этом на ответы типа «совсем не удовлетворены» приходится (как и в 2016 г.) весьма ощутимая доля (до 28,6 \% у респондентов в возрасте 55-59 лет). Отметим, что респондентов, заявивших о том, что они полностью удовлетворены материальным положением своей семьи в каждом из анализируемых периодов, крайне мало.

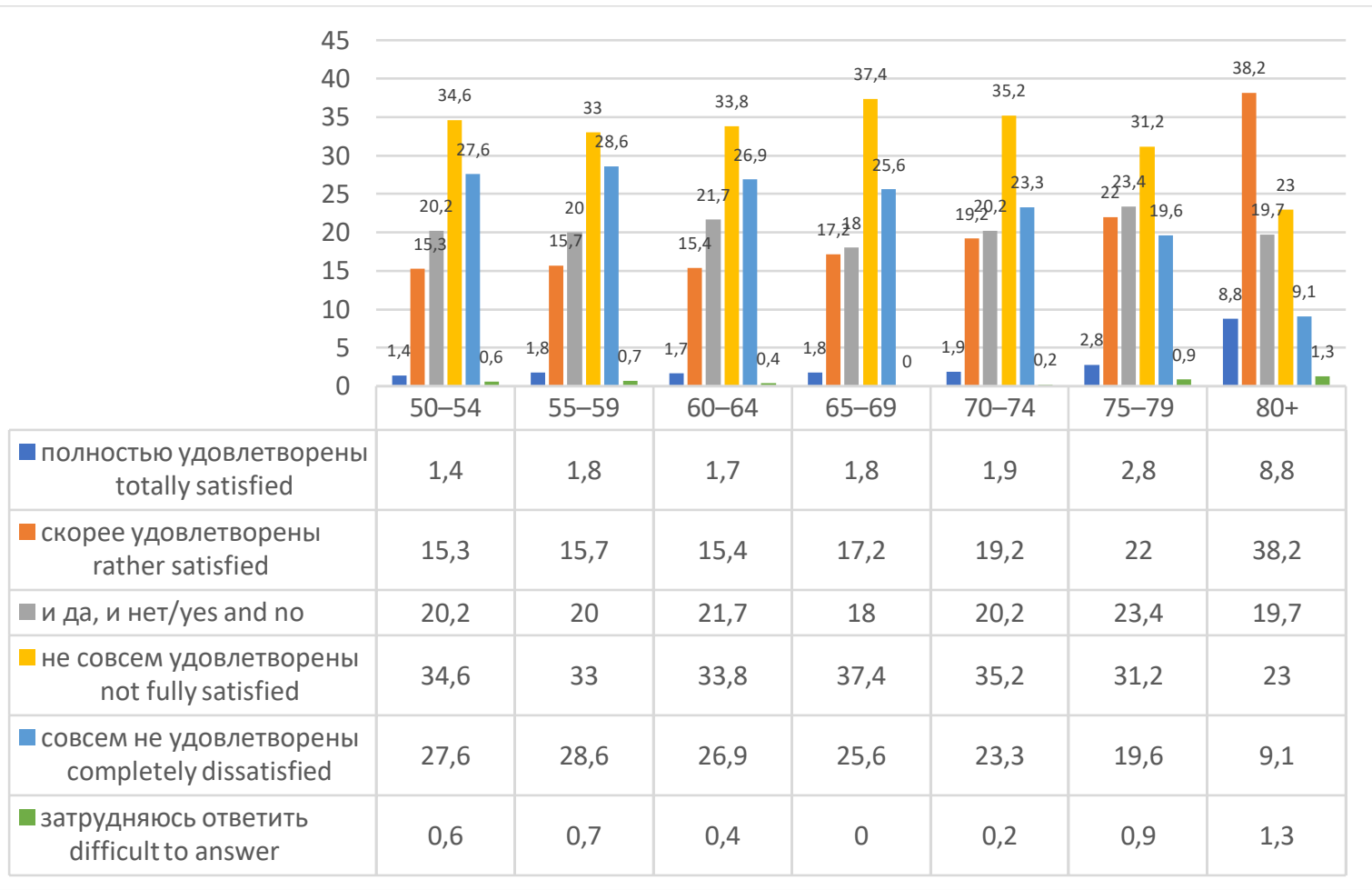

Pис. 2. Структура ответов респондентов различных возрастных групп об удовлетворенности материальным положением семьи за год в 2018 г. (\%) Fig. 2. Structure of answers of respondents of different age groups about satisfaction with the financial situation of the family in 2018 (\%)

Обобщение данных об ответах респондентов различного возраста на вопросы о динамике и удовлетворенности материальным положением семьи, позволяет перейти к более детальному изучению каждого из названных выше магистральных направлений трудовой траектории человека. Их исследование позволит уточнить и конкретизировать предварительно сделанные выводы, выявить специфические факторы, определившие типичные для каждой возрастной группы респондентов ответы на вопросы о динамике и удовлетворенности их материальным положением.

\section{Траектория «Занятость по найму»}

В ходе исследования авторы данной работы исходили из предварительного вывода о том, что значительная часть траекторий вовлеченности пожилых людей в социум 
проходит через рынок труда. Основным аргументом этому является особая роль данного рынка в системной трансформации современного общества, при этом для исследовательского фокуса наиболее важно то, что рынок труда, традиционно являясь механизмом регулирования совокупного спроса на наемный труд и его предложения, в последние годы представляет собой форпост для дискурса об одном из наиболее важных вызовов современности: стремительного старения населения. Именно на рынке труда в значительной мере манифестируются механизмы адаптации к этой новой социально-экономической реальности.

Оценивая распределение положительных ответов представителей различных возрастных групп (от 50 до 80 лет и старше) на вопрос о наличии у них на прошлой неделе оплачиваемой работы или доходного занятия (рис. 3), следует отметить не только весьма ожидаемые итоги о том, что максимальные значения таких ответов дали представители самой молодой из анализируемых возрастной группы (50-54 лет) на протяжении всего анализируемого периода: об этом заявили 77,9 \% от опрошенных этой возрастной группы в 2014 г., 78,9 \% - в 2016 г. и 81,1 \% - 2018 г. Наименьшие значения положительных ответов на вопрос о наличии оплачиваемой работы или доходного занятия также ожидаемо характерны для представителей самой старшей группы респондентов (80 лет и более) менее 0,5 \% за весь период. Важно отметить, что в наиболее молодой (50-54 года) и следующей за ней возрастной группе (55-59 лет) есть прирост числа ответивших положительно на этот вопрос за все три периода (всего на 3,2 \% для 50-54-летних и на 1,1 \% для 55-59-летних). При этом на фоне общего «ступенчатого» снижения степени трудовой активности респондентов по мере повышения их возраста, наблюдаемого в каждом из трех периодов, заслуживает внимания динамика этого процесса у представителей смежных возрастных групп. В группе 55-59 лет снижение занятости по сравнению с 50-54-летними составило 23,9 \% в 2014 г., 24,4 \% - в 2016 г. и 32,7 \% - в 2018 г. Схоже выглядит понижающаяся динамика занятости при сравнении ответов респондентов в возрасте 55-59 и 60-64 лет (она снижается на 27,7 \% в 2014 г., на 27,4 \% - в 2016 г., на 28,8 \% - в 2018 г.). Таким образом, «возрастные ступеньки» на рис. 3 неравные: если в трудовые отношения вовлечены примерно 8 из 10 людей в возрасте 50-54 лет, то в возрасте 55-59 лет таких только половина, среди людей 60-64 лет продолжает работать лишь каждый четвертый, а среди 65-69 летних - примерно каждый восьмой.

Здесь важно добавить международный аспект это вопроса. Говоря о том, что если в возрасте до 55 лет в РФ работают примерно столько же людей, сколько и в развитых странах, а в возрасте 55-65 лет работающих становится почти на 10 \% меньше, международные эксперты видят здесь в качестве основной причины относительно низкий уровень здоровья людей старшего возраста. Состояние здоровья российских мужчин и женщин резко падает после 50 лет, в то время как до 50 лет самооценка здоровья россиян находится на уровне их ровесников из развитых стран, но после 50 она снижается до уровня развивающихся стран [25].

Распределение ответов респондентов на вопрос о месте их работы (рис. 4) отражает преобладание у представителей всех возрастных групп в каждом раунде опросов решений о работе на предприятиях или в организачиях. Минимальное значение за период-64 \% (у людей 80 лет и старше в 2016 г.), максимальное - 100 \% у этой же группы в 2014 г. Эти данные также отражают самую заметную динамику занятости на предприятиях и в организациях в пределах одной и той же возрастной группы за весь период наблюдений. 


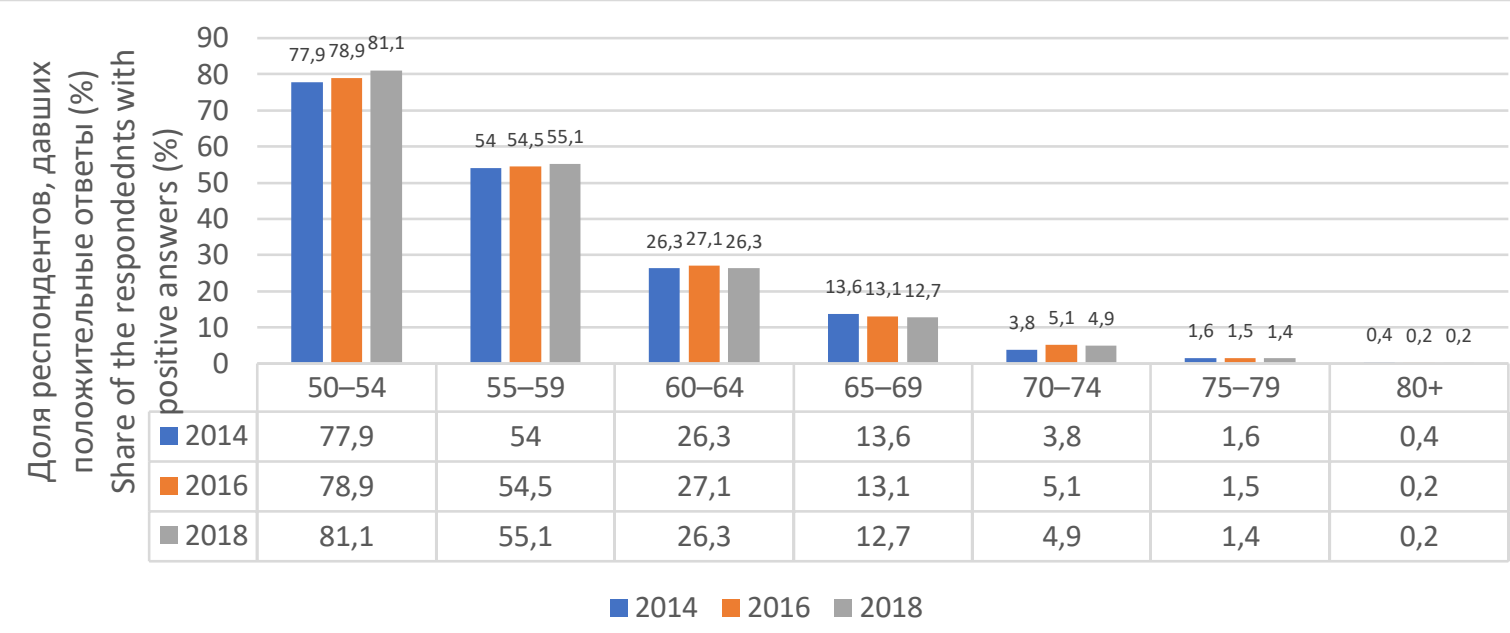

Рис. 3. Распределение положительных ответов представителей различных возрастных групп на вопрос о наличии на прошлой неделе оплачиваемой работы или доходного занятия, \% от общего числа опрошенных соответствующей возрастной группы

Fig. 3. Distribution of positive answers of representatives of different age groups to the question about the presence of a paid job or profitable occupation last week, $\%$ of the total number of respondents in the corresponding age group

При этом в 2014 г доля таких респондентов составила от 81 \% (среди 50-54-летних) до $100 \%$ (у респондентов в возрасте 80 лет и старше). В 2016 г. она колебалась от минимума в 64 \% (для лиц в возрасте 80 лет и старше) до максимума в 88 \% (для граждан 7579 лет). В 2018 г. во всех возрастных группах эти значения были близки (от 80,6 до 83,4 \%).

Все остальные варианты ответов респондентов по поводу места работы многократно уступают выбору в пользу работы на предприятиях или в организациях, однако часть из них (особенно в динамике) заслуживает внимания. Так, максимальная доля граждан, занятых на предприятиях индивидуального предпринимателя или семейном предприятии в 2014 г., была зафиксирована для возрастной группы 65-69 лет (на уровне 6,6 \%), в 2016 г. - у граждан 50-54 лет (6,5\%), в 2018 г. - в этой же возрастной группе (50-54 года), но на значительно более высоком уровне - 10,9\%. В целом отмечается увеличение доли людей всех возрастов, занятых на предприятиях индивидуального предпринимателя или семейном предприятии в 2018 г. по сравнению с 2014 и 2016 гг. Для граждан 50-54 лет эта доля за весь период возросла на 82 \% (с 6 \% в 2014 г. до 10,9 \% в 2018 г.). Для граждан 55-60 и 61-64 лет эта доля к 2018 г. возросла в 1,5 раза. Несколько ниже такая динамика в более старших возрастных группах, но она также прослеживается достаточно явно.

$B$ фермерском хозяйстве занята очень незначительная доля людей старшего возраста за весь период наблюдений. В 2014 г. на эту сферу приходилось от 0,5 \% занятых (минимум, относящийся к возрасту 65-69 лет) до 1,1 \% (максимум, относящийся к лицам в возрасте 75-79 лет). В 2016 г. - от 0,3 \% (минимум для людей в возрасте 65-64 и 6569 лет) до $9 \%$ (максимум для самых старших респондентов (80 лет и более)). В 2018 г. минимальное количество занятых в фермерском хозяйстве пришлось на возрастную группу 60-64 года $(0,4 \%)$, а максимальное - на людей в возрасте 80 лет и старше $(8,3 \%)$. Заметной динамики занятости в фермерском хозяйстве в пределах одних и тех же возрастных групп в целом за анализируемый период не выявлено. 
В сфере предпринимательской деятельности без образования юридического лица лидерами по занятости являются наиболее молодые представители анализируемых возрастных групп (50-54 и 55-59 лет). Важно отметить, что несмотря на невысокие в целом значения занятости такого рода, в 2018 г. наблюдается существенное увеличение количества людей, занятых предпринимательством практически во всех возрастных группах. Если максимальная доля пожилых предпринимателей в 2014 г. составляла 1,4 \%, то в 2018 г. она удвоилась практически в каждой возрастной группе, достигнув максимального значения 3,2 \% у людей в возрасте 75-79 лет.

Доля занятых по найму у физических лии и индивидуальных предпринимателей в 2014 г. составляла от 7 \% (максимум, достигнутый в возрастной группе 50-54 года) до 3,5 \% (минимум, характерный для людей в возрасте 75-79 лет). В 2016 г. эта доля была более стабильной для представителей всех возрастных групп и колебалась в пределах от 5,8 \% (для респондентов в возрасте 60-64 лет) до 7,6 \% (для граждан 70-74 лет).

Доля занятых на индивидуальной основе в целом незначительна за весь период наблюдений. Ее минимальное значение составило $0 \%$ у граждан в возрасте 80 лет и старше в 2014 г., а максимальное - 8,3 \% в этой же возрастной группе в 2018 г. Эти данные также отражают самую заметную динамику занятости в том аспекте в пределах одной и той же возрастной группы за весь период. По годам исследования диапазон занятости на индивидуальной основе характеризуется следующими данными:

- в 2014 г.: от 1,2 \% в возрасте 75-79 лет до 6,4 \% в возрасте 70-74 года;

- в 2016 г.: от 2,8 \% в возрасте 55-59 лет до $9 \%$ в возрасте 80 лет и более;

- в 2018 г.: от 1,5 \% в возрасте 75-79 лет до 8,3\% в возрасте 80 лет и более.

Доля занятых в собственном домашнем хозяйстве по производству товаров $и$ услуг также незначительна за весь период наблюдений: она составляла от 0,2 \% для граждан 60-64 лет в 2016 г. (минимум) до 9\% для граждан 80 лет и старше в 2016 г. (максимум). По годам исследования диапазон занятости в собственном домашнем хозяйстве по производству товаров и услуг составил:

- в 2014 г.: от 0 \% в возрасте 80 лет и старше до 2,4 \% в возрасте 75-79 лет;

- в 2016 г.: от 0,2 \% в возрасте 60-64 года до 9\% в возрасте 80 лет и старше;

- в 2018 г.: от 0 \% в возрасте 80 лет и старше до 1,5 \% в возрасте 70-74 и 75-79 лет.

Заметной динамики занятости в пределах одних и тех же возрастных групп в целом за анализируемый период не выявлено.

Анализ ответов респондентов на вопрос о режиме работы (рис. 5) показал, что на протяжении всех периодов наблюдений граждане всех анализируемых возрастных групп предпочитали работу с полным рабочим днем (сменой) или полной рабочей неделей. Максимальной значение таких ответов (91,3 \%) было у граждан 50-54 лет в 2014 г., а минимальное (30 \%) - у граждан старше 80 лет в 2016 г. При этом ответы о занятости на условиях полного дня в каждом раунде наблюдений ожидаемо снижаются по мере повышения возраста опрашиваемых.

Однако динамика этого процесса неравномерна. Так, в 2014 г. такое снижение было наиболее быстрым при переходе от возрастной группы 65-69 лет к 70-74 (на 8,2\%) и при переходе к самой старшей возрастной группе 80 лет и более (на 16,6 \%), наименышим - при переходе от группы 70-74 года к группе 75-79 лет (на 1,1 \%). В 2016 г. наибольшее снижение ответов о полном рабочем рабочем дне наблюдается между теми же самыми возрастными группами, а в 2018 г. наиболее быстро снижается доля работающих полный рабочий день во всех возрастных группах, начиная с 65-69 лет и особенно у граждан 80 лет и старше (на 21 \%). Разрыв в ответах о выборе полного рабочего дня у представителей одних и тех же возрастных групп по разным раундам исследования несущественный. 


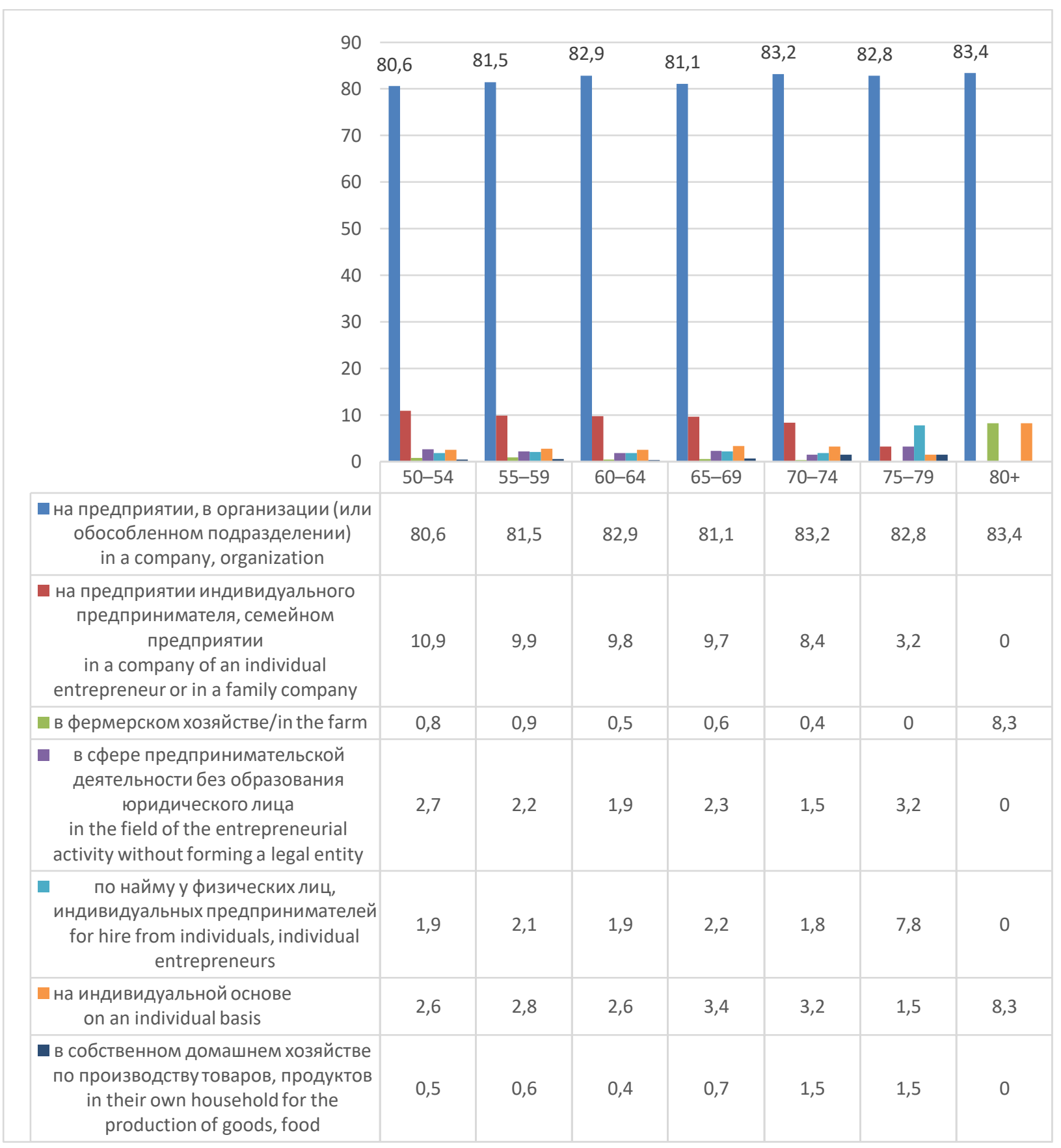

Puс. 4. Распределение ответов представителей различных возрастных групп на вопрос о месте основной работы (2018), \% от общего числа опрошенных соответствующей возрастной группы

Fig. 4. Distribution of answers of representatives of different age groups to the question about the place of their main job (2018), \% of the total number of respondents in the corresponding age group

При анализе ответов респондентов, сообщивших о работе неполный рабочий день (смену) или неполную рабочую неделю обращает на себя следующее: минимальное количество ответов такого рода (3,7 \%) у самых молодых респондентов (50-54 года) в 2014 г., максимальное - $(40 \%)$ у граждан 80 лет и старше в 2016 г. Такой тип ответов ожидаемо возрастает в каждом раунде исследования по мере повышения возраста 
респондентов. Темп прироста таких ответов ускоряется при переходе к самой старшей возрастной группе и составил 6,2 \% в 2014 г., 16,5 \% - в 2016 г. и 7,9 \% - в 2018 г.

Ответы о гибком режиме работы (гибкий, скользящий рабочий день) показали его относительно низкую распространенность. Максимальные ответы такого рода были у самых старших респондентов в 2016 г. (40 \%), минимальные - у самых молодых опрашиваемых в 2014 г. (5 \%). Для этого типа ответов характерна та же динамика, что и для неполной занятости: общая повышательная тенденция по мере увеличения возраста респондентов, при этом значения, полученные для неполной занятости и гибкого режима работы по отдельным возрастным группам, близки и примерно равны за весь период наблюдений.

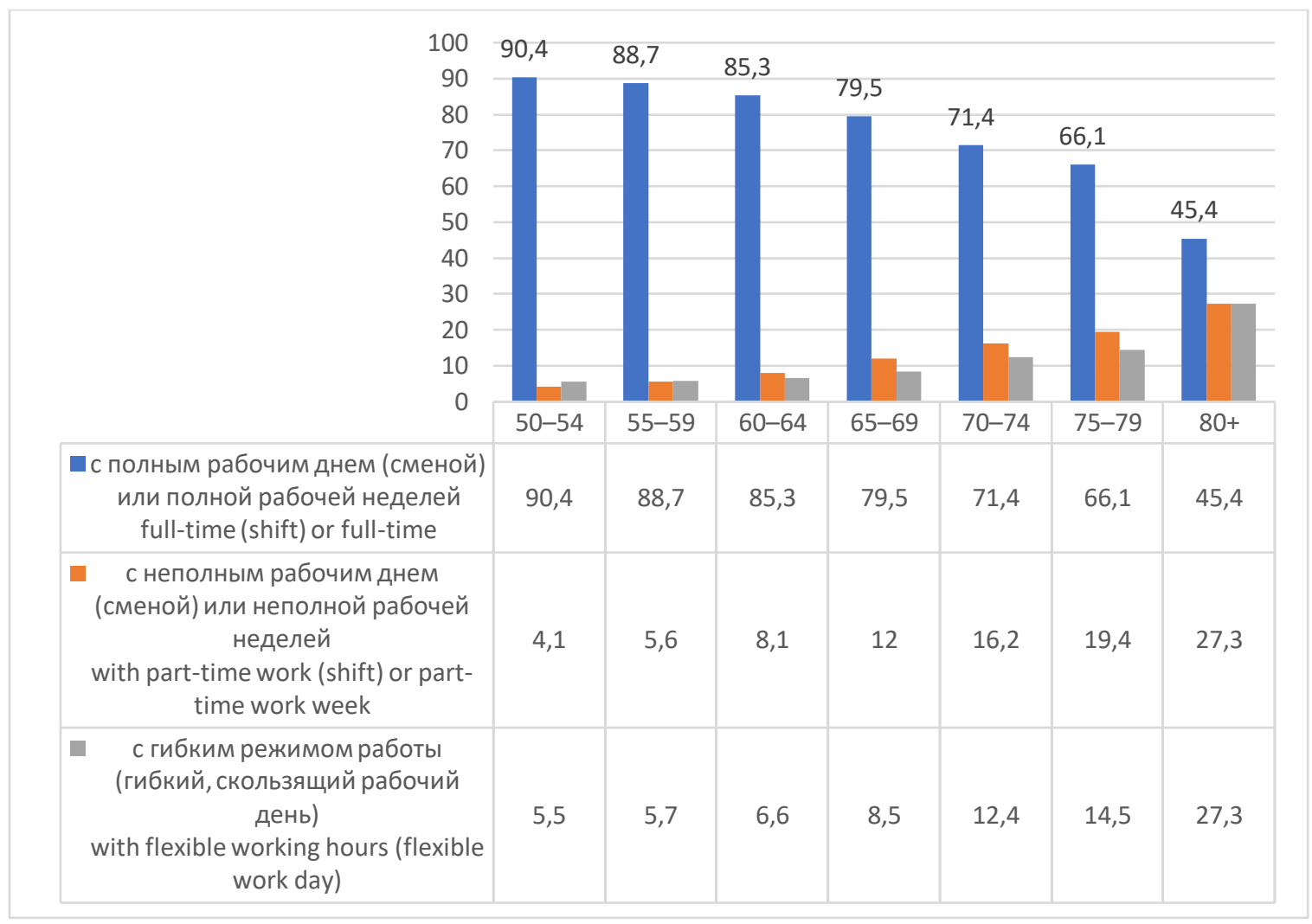

Pис. 5. Распределение ответов представителей различных возрастных групп на вопрос о режиме их работы в 2018 г., \% от общего числа опрошенных соответствующей возрастной группы

Fig. 5. Distribution of answers of representatives of different age groups to the question about their work schedule in 2018, \% of the total number of respondents in the corresponding age group

Анализ соответствия выполняемой работы полученной специиальности представлен на рис. 6. Наиболее широкий разброс в ответах респондентов по годам здесь был у представителей самой старшей возрастной группы. В 2014 г. эта группа максимально заявила о полном соответствии (73,4 \%). При этом та же группа в 2016 г. дала аналогичную оценку лишь в 9,1\% случаев, а в 2018 г. - в $44 \%$. По остальным возрастным группам по каждому году исследования респонденты разделились примерно поровну на тех, кто считает, что их работа полностью (или частично) соответствует полученной специальности, и тех, кто считает, что их работа не по специальности. Такие оценки дают основание для нескольких предположений. 


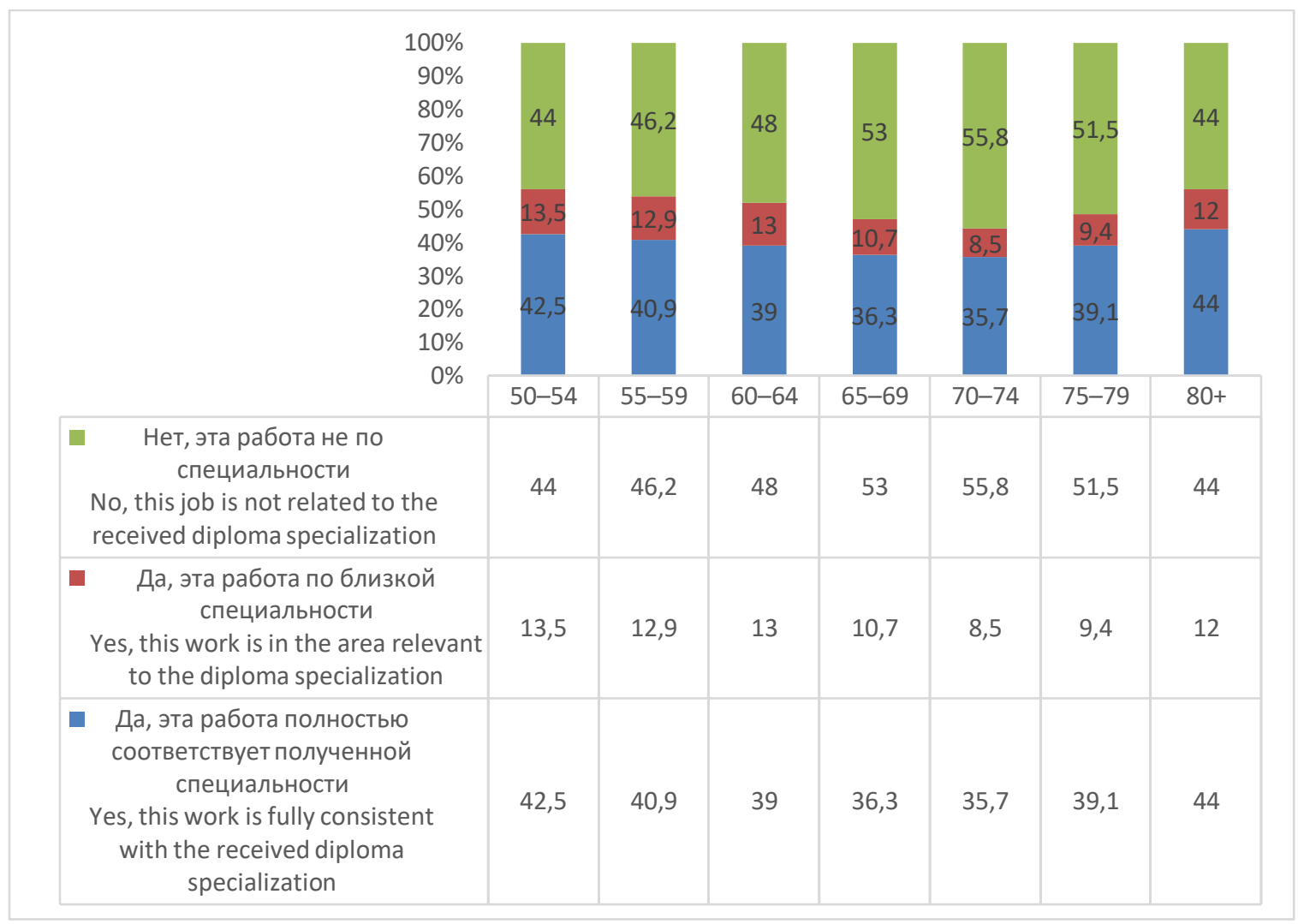

Рис. 6. Распределение ответов представителей различных возрастных групп на вопрос о соответствии их основной работы полученной специальности в 2018 г., \% от общего числа опрошенных соответствующей возрастной группы

Fig. 6. Distribution of answers of representatives of different age groups to the question about the correspondence of their main work to the received specialty in 2018, $\%$ of the total number of respondents in the corresponding age group

Во-первых, об отражении в этих данных последствий существенной трансформации российской экономики, произошедшей в последние десятилетия. Переход к рыночной экономике, глобальные технологические и структурные сдвиги видоизменили рынок труда, в частности привели к необходимости (иногда радикальной) смены сферы деятельности для очень большой доли граждан, в том числе людей среднего и старшего возраста. Многие из тех, кто сегодня продолжает трудиться, получили образование в 60-70е годы XX в. Выбранные в то время специальности к настоящему моменту зачастую не только не потеряли актуальность, но и попросту исчезли, не оставив людям иного выбора, кроме как работать не по основной специальности.

Во-вторых, высокая доля граждан в различных возрастных группах, заявивших о том, что их работа не соответствует полученной специальности, может быть отражением высокого уровня адаптивности трудового потенциала граждан старших возрастов к требованиям современного рынка труда. Действительно, занятость в старших возрастах характеризуется примерно тем же соответствием образованию, что и у граждан 50-54 лет. Этот вывод косвенно подтверждается экспертным мнением о высоком уровне компетенций, сформированных у граждан России до начала рыночных преобразований, ценность которых за последние десятилетия не только не девальвировалась, но и обеспечивает людям гарантированную занятость за официальными границами трудоспособного возраста [26]. 
В-третьих, такая ситуация может быть отражением готовности пожилых людей соглашаться на выполнение почти любой оплачиваемой работы, в том числе не соответствующей их специальности, в силу низкого уровня доходов (невысокой пенсии, необходимости материальной поддержки других членов семьи). В этом случае решение человека старшего возраста о выполнении работы, не соответствующей полученной специальности, является скорее вынужденным решением, результатом внешних обстоятельств, чем решением, продиктованным желанием продлить самореализацию в труде.

Таким образом, для детализации причин несовпадения выполняемой работы полученной ранее специальности, на наш взгляд, требуются: фиксация продолжительности этапа трудовой биографии, в котором человек работал не по специальности; уточнение квалификационного уровня работы, выполняемой представителями старших возрастных групп в настоящее время; выявление личных мотивов, определяющих желание продолжить трудовую деятельность за границами трудоспособного возраста.

Продолжением анализа затронутых выше вопросов является изучение мнений респондентов о наличии у них специальной профессиональной подготовки для нынешней работы. На рис. 7 видно, что по мере повышения возраста респондентов доля положительных ответов на этот вопрос снижается в каждом из анализируемых периодов, при этом максимальное значение здесь зафиксировано у граждан 50-54 лет в 2018 г. (34,7 \%), а минимальное - у граждан 75 лет и старше в 2016 г. (10,4 \%). Важно, что за анализируемый период практически в каждой возрастной группе наблюдается прирост положительных ответов на данный вопрос, причем самый значительный - в 2018 г. Исключением здесь является возрастная группа 70-74 года, в которой рассматриваемый показатель не имел устойчивой динамики: в 2014 г. он составлял 20,5\%, в 2016 г. - снизился до $11,4 \%$, а в 2018 г. достиг $24,2 \%$.

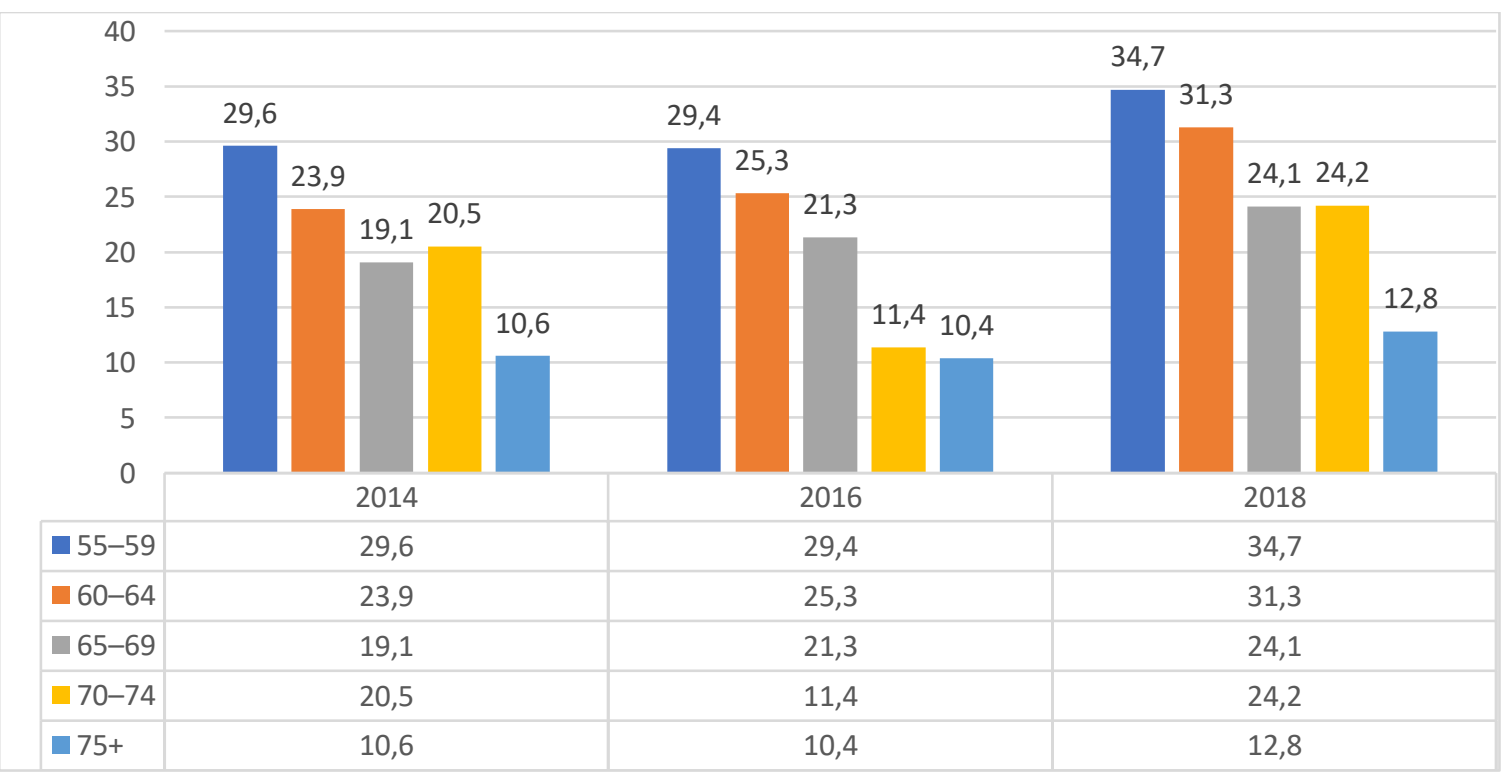

Рис. 7. Доля положительных ответов на вопрос о наличии у представителей различных возрастных групп спещиальной профессиональной подготовки для нынешней работы в 2014, 2016, 2018 г2., \% от общего числа опрошенных соответствующей возрастной группы

Fig. 7. Share of positive answers to the question about whether representatives of different age groups have special professional training for current work in 2014, 2016, 2018, $\%$ of the total number of respondents in the corresponding age group 
К сожалению, имеющиеся статистические данные не дают возможности идентифицировать инициаторов решений о получении гражданами специальной профессиональной подготовки, а также не позволяет определить субъектов, понесших соответствующие затраты (сами граждане, работодатели, государство или комбинированные варианты). Очевидно, что в следующей волне обследования следует ожидать значительной положительной динамики по данному направлению за счет вступления в 2019 г. в силу Национального проекта «Демография» и начала масштабной реализации программ обучения граждан в возрасте от 50 лет и старше, а также лиц предпенсионного возраста со счет бюджетных ресурсов. Хорошим подтверждением и яркой иллюстрацией развития этого процесса являются материалы сайта [27], организованного Федеральной службой по труду и занятости и Союзом «Ворлдскиллс Россия».

Интересны ответы респондентов о наличии у них навыков или квалификации для выполнения более сложной работы (рис. 8). Положительные ответы представителей всех возрастных групп в каждом из трех периодов наблюдений оказались весьма высокими и составили от 38,2 \% (минимум - у граждан 45 лет и старше в 2018 г.) до 52,3 \% (максимум - у граждан 50-54 лет в 2014 г.). Важно отметить, что разрывы в таких оценках между самыми молодыми и самыми пожилыми респондентами в среднем не превышают $10 \%$. Поэтому даже учитывая субъективность и односторонность таких оценок, высокую вероятность их завышения, они свидетельствуют о существенной недовостребованности и (или) недооценённости знаний, умений, навыков, которыми располагают российские работники старших возрастов.

\begin{tabular}{|c|c|c|c|c|}
\hline 60 & $52,349,548,245,8$ & $49,246,7$ & 47,1 & 48,5 \\
\hline 40 & & & & 38,2 \\
\hline 30 & & & & \\
\hline 20 & & & & \\
\hline 10 & & & & \\
\hline 0 & 2014 & 2016 & 2018 & \\
\hline$=50-54$ & 52,3 & 49,2 & 47,1 & \\
\hline 55-59 & 49,5 & 46,7 & 44,5 & \\
\hline 60-64 & 48,2 & 44,1 & 42,9 & \\
\hline 65-69 & 45,8 & 44,9 & 45 & \\
\hline$\square 70-74$ & 42,2 & 48,2 & 48,5 & \\
\hline $75+$ & 45,5 & 40,4 & 38,2 & \\
\hline
\end{tabular}

Pис. 8. Доля положительных ответов на вопрос о наличии у представителей различных возрастных групп навыков или квалификации для выполнения более сложной работы в 2014, 2016, 2018 г2., \% от общего числа опрошенных соответствующей возрастной группы

Fig. 8. Share of positive answers to the question about whether representatives of different age groups have skills or qualifications to perform more complex work in 2014, 2016, $2018, \%$ of the total number of respondents in the corresponding age group

В 2018 г. в КОУЖ впервые был включён вопрос о потребности респондентов в получении знаний в области информационных технологий (рис. 9). Интересно, что практически во всех исследуемых возрастных группах результаты получились похожими: 
примерно треть опрошенных заявили о наличии у них такой потребности, а 2/3 уверены в том, что такой потребности у них нет. Эти результаты также не подлежат однозначной интерпретации, поскольку, возможно, они отражают «цифровое диссидентство» части пожилых людей и их нежелание овладевать навыками в этой сфере; свидетельствуют о «низком качестве» части рабочих мест, занимаемых представителями старших возрастов, для которых знания в области цифровых технологий не важны; показывают, что часть опрашиваемых слабо осведомлена о возможностях применения информационных технологий в профессиональной деятельности и (или) в личных целях и поэтому не проявляет к ним должного интереса; часть опрашиваемых уже прошла значительный путь в этом направлении и к настоящему время чувствует себя в этой сфере весьма уверенно.

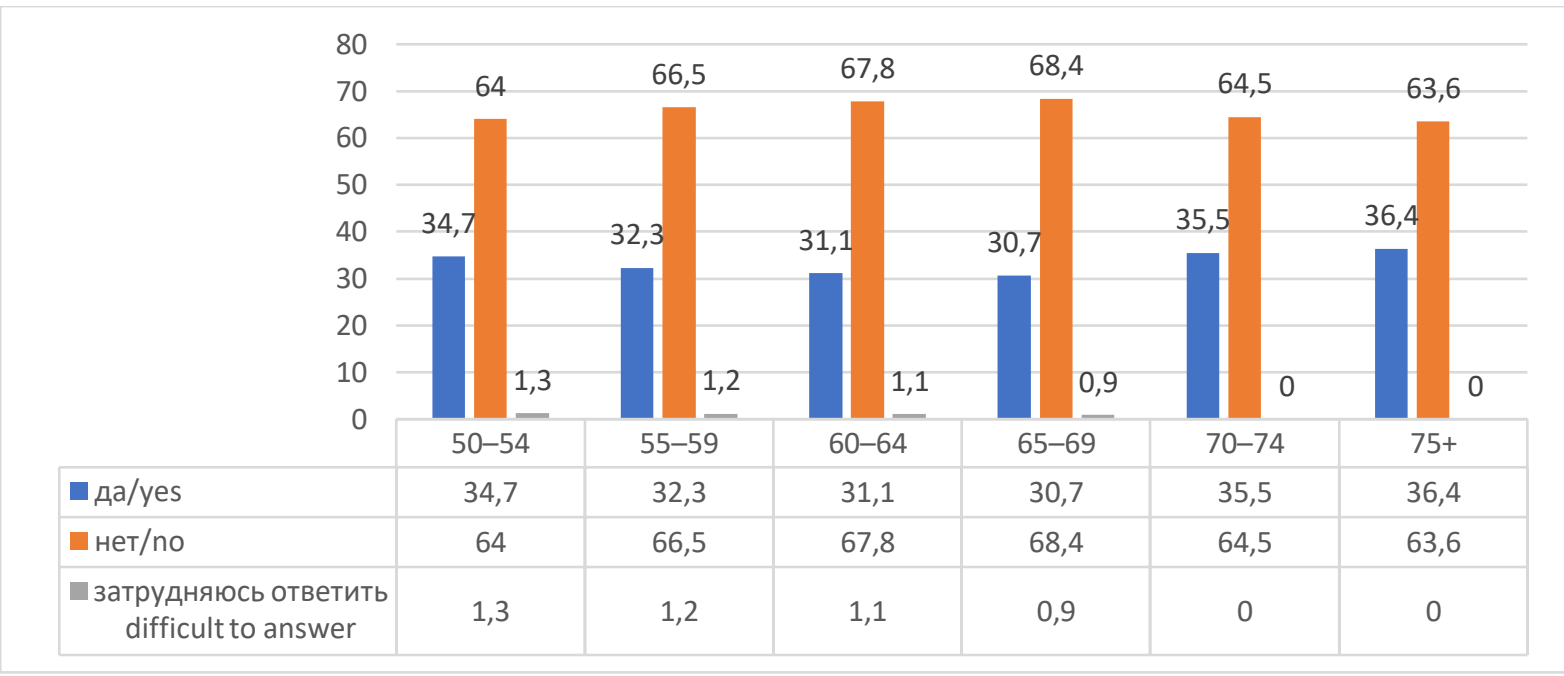

Puc. 9. Распределение мнений представителей различных возрастных групп о потребности в получении знаний в области информационных технологий в 2018 г., в \% от общего числа опрошенных соответствующей возрастной группы Fig. 9. Distribution of opinions of representatives of different age groups about the need to acquire knowledge in the field of information technology in 2018, \% of the total number of respondents in the corresponding age group

Распределение ответов на вопрос о характере основной работы с точки зрения физических затрат на ее выполнение (рис. 10) позволяет сделать следующие выводы. Доля граждан любой из анализируемых возрастных групп, заявивших о своей работе как об «очень тяжелой», очень мала в каждом периоде наблюдений и колеблется в пределах 0 до 3,8 \%. Значение этого показателя на уровне $9 \%$ для граждан 80 лет и старше в 2018 г. с высокой вероятностью следует считать статистическим выбросом, обусловленным традиционно малочисленной выборкой в данной возрастной группе. Доля респондентов, заявивших, что их работа «тяжелая», несколько выше. Максимальную оценку $(18,2$ \%) здесь дали 50-54-, 55-59-летние опрашиваемые в 2018 г. Минимальную (1,5 \%) - граждане в возрасте 75 лет и старше в 2016 г. Во всех периодах опросов по мере повышения возраста доля опрашиваемых, считающих свою работу тяжелой, заметно снижается. При этом оценки работы как «легкой» по мере повышения возраста респондентов возрастают в каждом периоде. В каждом из периодов во всех возрастных группах оценки работы как средней тяжести и легкой существенно превосходили совокупность ответов «тяжелая» и «очень тяжелая». 


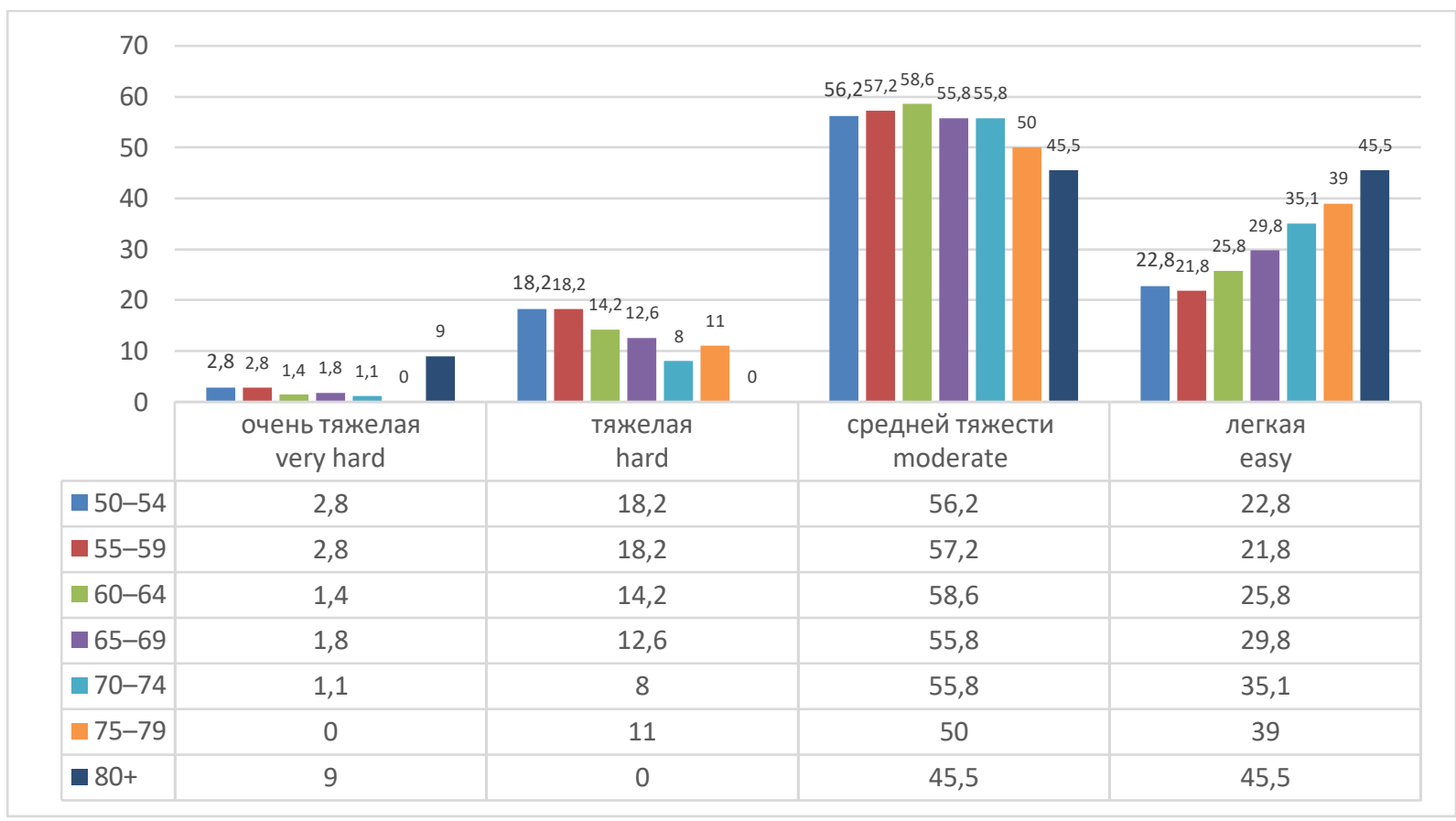

Pис. 10. Распределение мнений представителей различных возрастных групп о характере основной работы с точки зрения физических затрат на ее выполнение в 2018 г., в \% от общего числа опрошенных соответствующей возрастной группы, с поправкой на пропущенные ответы

Fig. 10. Distribution of opinions of representatives of different age groups about the nature of the main work in terms of physical costs for its implementation in 2018, \% of the total number of respondents in the corresponding age group, adjusted for missing answers

Ответы на вопрос о количестве часов в неделю, отработанных на основной работе, включая сверхурочную (рис. 11), показывают постепенное и плавное сокращение по мере повышения возраста респондентов от максимального значения в 41 час у граждан 50-54 лет в 2014 г. до 25,6 часа у граждан 80 лет и старше в 2016 г. Максимальная разница в количестве часов, отработанных в неделю при сравнении самых молодых и самых старших респондентов, составила 36 \% (2016), минимальная - 27 \% (2014). К сожалению, по имеющимся данным невозможно сделать вывод о том, какая часть оцениваемого времени имеет отношение к нормальной продолжительности рабочего дня, а какая - к сверхурочной, поскольку практически все представленные данные не превышают нормальную продолжительность рабочей недели, установленную российским трудовым правом на уровне 40 часов.

Оценка удовлетворенности заработной платой (рис. 12) позволяет сделать следующие выводы. По мере повышения возраста респондентов, как правило, растет степень их удовлетворенности заработной платой: в каждом из периодов она увеличивается приблизительно с 1/3 в группе 50-54 летних, до 3/4 в группе 80 лет и старше. Соответственно, по мере повышения возраста в той же динамике сокращается доля респондентов, не вполне и совсем не удовлетворенных заработной платой. В наибольшей мере неудовлетворенность заработной платой прослеживается в наиболее молодых возрастных группах: 50-54 и 55-59 лет. Снижение такой неудовлетворенности в более старших группах во многом объяснима появлением в структуре доходов нового источника - пенсии, поэтому любая заработная плата в этом случае выглядит как весьма привлекательный и не всегда очевидный источник дополнительного дохода. 


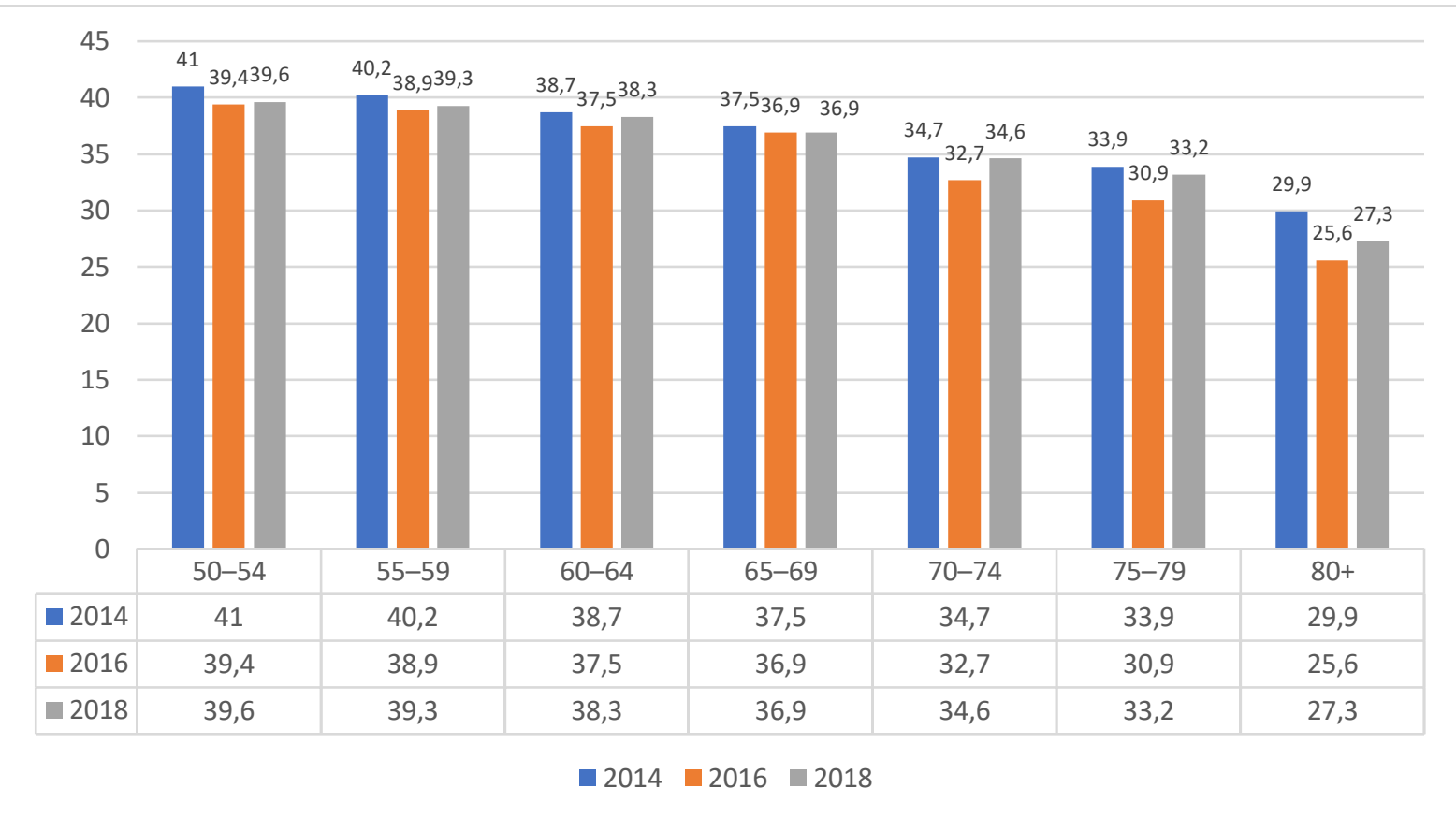

Pис. 11. Распределение мнений представителей различных возрастных групп о количестве часов в неделю, отработанных на основной работе, включая сверхурочную работу

Fig. 11. Distribution of opinions of representatives of different age groups on the number of hours per week worked on the main job, including overtime work

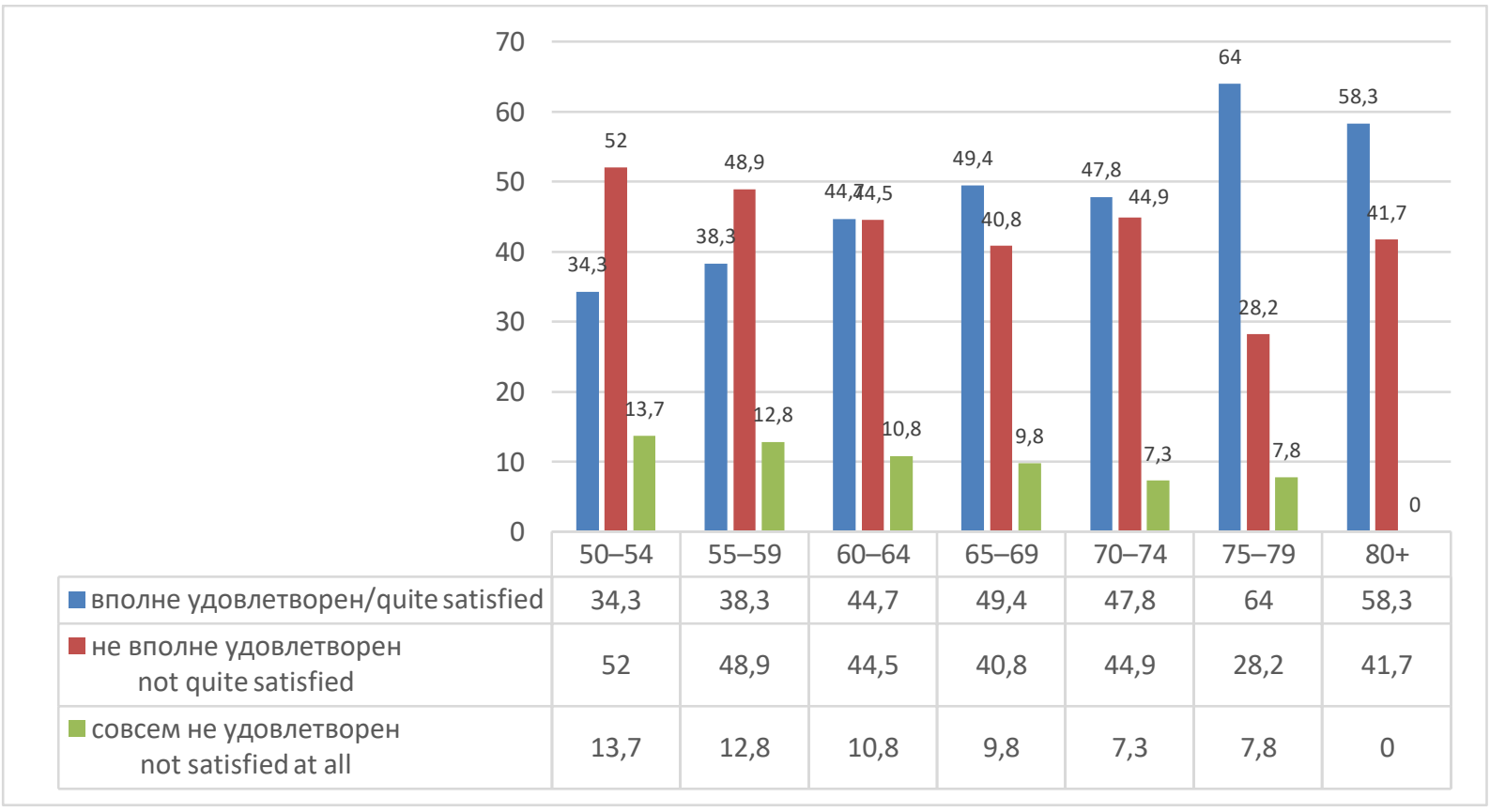

Рис. 12. Распределение мнений представителей различных возрастных групп об их степени удовлетворенности заработной платой в 2018 г., в \% от общего числа опрошенных соответствующей возрастной группы

Fig. 12. Distribution of opinions of representatives of different age groups about their degree of satisfaction with wages in 2018, in \% of the total number of respondents in the corresponding age group 
Оценка удовлетворенности надежностью работ за каждый из трех периодов наблюдений имеет ту же общую динамику по всем возрастным группам, что и удовлетворённость заработной платой: по мере повышения возраста респондентов она стабильно растет. В 2014 г. - с 69,4 \% у граждан 50-54 лет до 93,3 \% у граждан 80 лет и старше; в 2016 г. соответственно с 68,3 до 82\%, а в 2018 г. - с 69,9 до 83,3\%. При этом удовлетворенность надежностью работы во всех возрастных группах ощутимо выше удовлетворённости заработной платой. Обратная динамика у оценок «не вполне удовлетворен» и «неудовлетворен» надежностью работы: они равномерно снижаются по мере повышения возраста респондентов (в общей сумме от $30 \%$ у представителей 50-54-летних до 9-18 \% (в разные годы) у 80-летних и более пожилых респондентов). При этом таких оценок в целом значительно меньше, чем оценок «вполне удовлетворён».

Оценки удовлетворенности респондентов различных возрастных групп выполняемыми обязанностями дали еще более впечатляющие результаты. В возрасте 50-54 лет не менее $3 / 4$ опрошенных вполне ими удовлетворены в каждый период наблюдений, а по мере повышений возраста респондентов это значение плавно увеличивается (до $91 \%$ в 2016 г., до $92 \%$ - в 2018 г. и до $100 \%$ - в 2014 г.) у граждан 80 лет и старше. Столь высокие оценки удовлетворённости выполняемыми обязанности несколько диссонируют с отмеченным выше мнением респондентов практически каждой возрастной группы о наличии у них навыков или квалификации для выполнения более сложной работы (рис. 8), однако они также могут отражать готовность респондентов выполнять свои текущие обязанности за относительно невысокую заработную плату (см. оценки удовлетворённости заработной платой на рис. 12).

Анализ соотношения между работающими в различных возрастных группах (по данным RLMS), оформленными официально и неофищиально, показал превалирование во всех возрастных группах и за все периоды исследования официально трудоустроенных граждан. Диапазон колебания этого показателя находится в пределах от 91 до 100 \%. Отметим, что такие результаты нельзя признать вполне надежными. Так, например, руководитель Центра трудовых исследований ВШЭ Владимир Гимпельсон отмечает, что «...если обратиться к мировому опыту и посмотреть, сколь велика неформальная занятость в странах с разным уровнем ВВП на душу населения, то нынешнему уровню экономического развития России будет примерно соответствовать ее доля в 25-30 \%» [28]. По данным Росстата, в конце 2016 г. доля «неформального» сектора от общего числа занятых в российской экономике составила 20,9\%, в конце 2018 г. - 20 \% [29]. Эти данные, безусловно, нельзя в полной мере применять ко всем работникам в рассматриваемых возрастных группах, но они дают основание усомниться в искренности респондентов при ответах на этот вопрос или отражают их желание дать на этот вопрос «социально приемлемый» ответ.

\section{Траектория «Самозанятость и предпринимательство»}

При исследовании траекторий самозанятости и предпринимательства пожилых людей авторы исходили из того, что активность такого рода не следует рассматривать как продиктованную исключительно экономическими мотивами, финансовыми нуждами и недостаточностью пенсии для приемлемого уровня потребления в старшем возрасте. Не менее важным стимулом для этого является для пожилого человека его «...востребованность и включенность в социальные и профессиональные отношения» [30, с. 90]. Благодаря этому самозанятость и предпринимательская активность пожилых людей представляют собой одну из наиболее важных и динамично развивающихся траекторий вовлеченности пожилых в современный социум. 
На рис. 13 представлено распределение вариантов ответов граждан различных возрастных групп, подтвердивших что выполняемая ими основная работа имеет отношение к самозанятости и предпринимательству. Здесь в процентах (от общего числа давших такие ответы) показаны доли респондентов, заявивших, что они заняты (1) в предпринимательстве без образования юридического лица, (2) заняты на индивидуальной основе или (3) в собственном домашнем хозяйстве по производству товаров. Дополнительной линией на рисунке показана доля (в \%) ответов об основной работе как имеющей отношение к самозанятости и предпринимательству от общего числа респондентов в соответствующей возрастной группе, заявивших о том, что они работают.

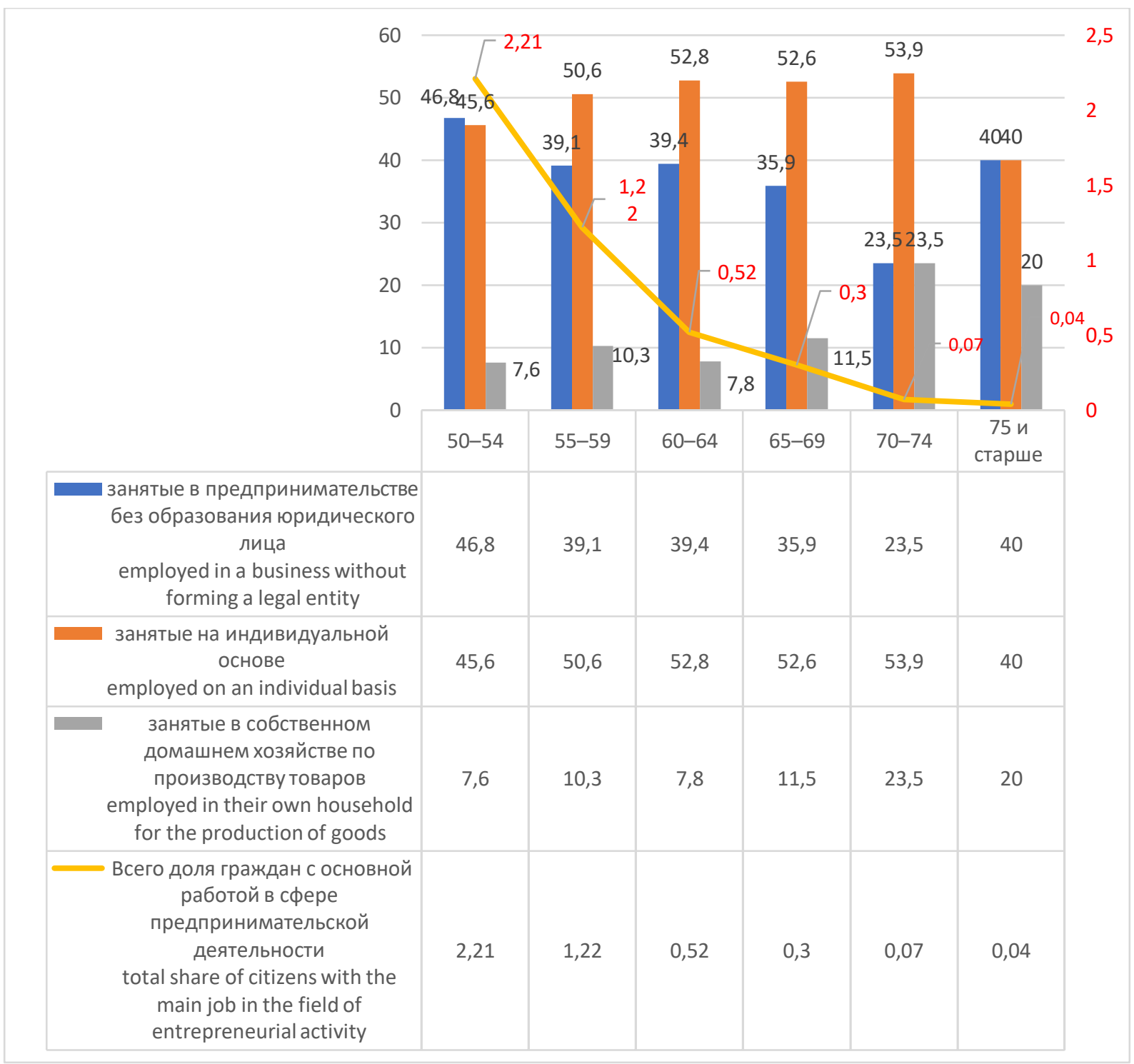

Рис. 13. Распределение ответов представителей различных возрастных групп на вопрос о видах основной работы, имеющей отношение к самозанятости и предпринимательству в 2018 г., \% от общего числа выбравших такие ответы в соответствующей возрастной группе

Fig. 13. Distribution of answers of representatives of different age groups to the question about the types of main work related to self-employment and entrepreneurship in 2018, $\%$ of the total number of those who chose such answers in the corresponding age group 
Здесь видно, что в наибольшей мере привлекательной для граждан всех возрастных групп является занятость на индивидуальной основе. Минимальное значение этого показателя зафиксировано у граждан 75 лет и старше в 2014 г. (33\%), максимальное - у граждан 70-74 лет в 2014 и 2016 гг. Во все три года наблюдения именно эта возрастная группа показывает пиковое значение доли занятости на индивидуальной основе. Доля граждан, занятых в предпринимательстве без образования юридического лиия, распределена по годам исследования неравномерно. В 2014 и 2016 гг. в ней оказались более молодые респонденты (не старше 69 лет) с постепенным снижением их доли по мере повышения возраста (с 29 до 13 \% в 2014 г., с 30 до 22 \% в 2016 г.) В 2018 г. доля граждан, занятых на индивидуальной основе, практически сравнивается с долей тех, кто выбрал предпринимательство без образования юридического лица (особенно это характерно для граждан в возрасте 50-54 и 70-74 лет), в промежуточных между ними возрастных группах доля тех, кто занят на индивидуальной основе, превышает долю занятых предпринимательством без образования юридического лица в 1,5-2 раза. Доля занятых в собственном домашнем хозяйстве увеличивается по мере повышения возраста респондентов и достигает максимума (в 67 \% в 2014 г., 29 \% в 2016 г. у граждан 75 лет и старше). В 2018 г. максимальная доля предпринимателей, ответивших, что они заняты в собственном домашнем хозяйстве, проходилась на возрастную группу 70-74 года $(23,5$ \%), что немногим выше, чем значение у следующей возрастной группы респондентов (75 лет и старше), где аналогичное значение составило 20 \%. При этом доля граждан, заявивших что их основная работа связана с предпринимательством, крайне мала практически во всех анализируемых возрастных группах за все периоды наблюдений и неуклонно снижается по мере повышения возраста респондентов. Максимальное значение этого показателя 2,21 \% у граждан 50-54 лет в 2018 г.

Эти данные хорошо согласуются с распределением ответов представителей различных возрастных групп об их работе на индивидуальной основе и в собственном домашнем хозяйстве (совокупно) среди всех работающих. Так, наиболее активными в этом отношении ожидаемо оказались граждане 50-54 лет с некоторым снижением этой доли от 2014г. (2,79\%) к 2018 г. (2,51 \%). При этом граждане в возрасте 55-59 лет за тот же период сохранили в этом распределении второе место с небольшим приростом соответствующих значений (с 1,74 \% в 2014 г. до 1,9\% в 2018 г.). Доля других возрастных групп в данном распределении незначительна и по мере повышения возраста респондентов снижается.

При анализе распределения представителей различных возрастных групп от общего количества подтвердивших, что источником средств к их существованию являются доходы от предпринимательской деятельности (рис. 14), также обращает на себя внимание снижение частоты таких ответов по мере повышения возраста респондентов: на долю лиц в возрасте 50-54 лет приходится $41 \%$ ответивших таким образом, в возрасте 55-59 лет - треть ответивших, а 60-64 лет - только $16 \%$. Таким образом, за весьма редким исключением, предпринимательство в России - удел преимущественно молодых людей, мировоззрение которых сформировалось в период системной трансформации общества. Граждане более старшего возраста традиционно склонны отказываться от попыток самореализации через предпринимательство, зачастую приоритезируя роль государства как основного и (или) единственного гаранта их благосостояния, обладающего монополией на поддержание приемлемого уровня жизни [31]. 


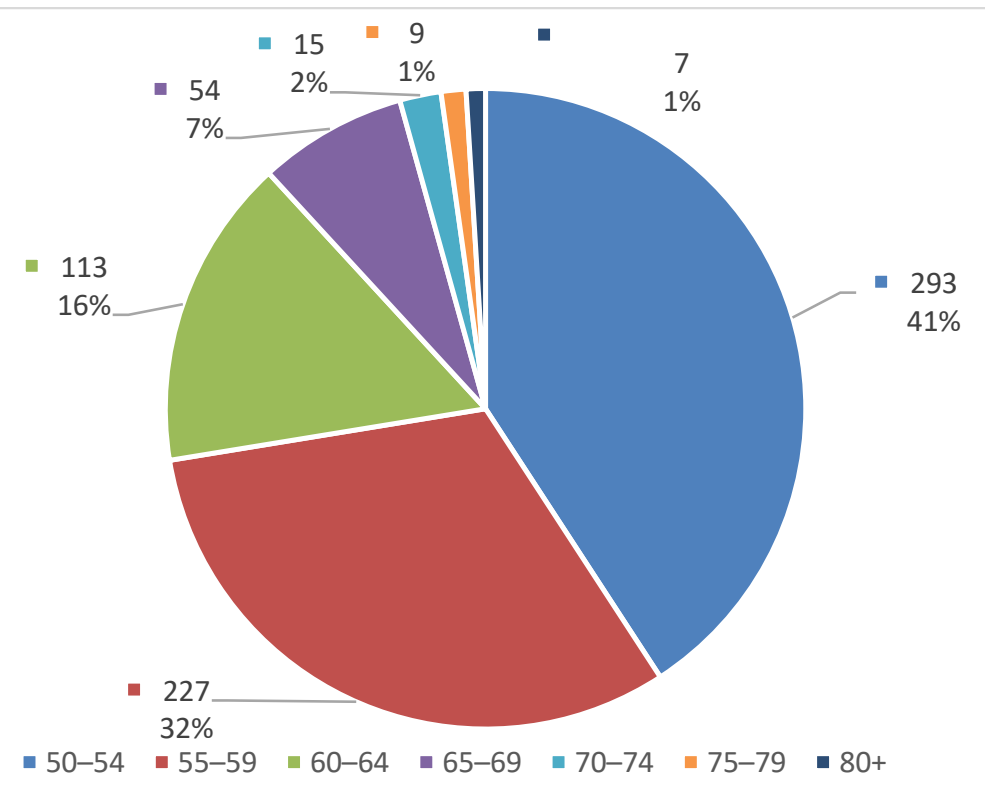

Puс. 14. Доля представителей различных возрастных групп от общего количества подтвердивших, что источником средств к существованию для них являются доходы от предпринимательской деятельности в 2018 г.

Fig. 14. Share of representatives of different age groups in the total number of those who confirmed that the source of their livelihood is income from entrepreneurial activity in 2018

Тем не менее данный вывод не является единственным и всеобъемлющим. Так, например, анализ домохозяйств, в которых занятость в предпринимательской сфере является главным источником доходов для их членов, показывает весьма высокий уровень их материального благосостояния (по сравнению с теми, кто остался в рамках традиционной концепции занятости и выбрал для себя наемный труд, рис. 15). Доходы домашних хозяйств, где граждане заняты предпринимательством (на фоне усредненного денежного дохода домохозяйств), оказываются до двух раз выше. Максимальный разрыв в таких значениях зафиксирован для домохозяйств, в составе которых есть представители возрастной группы 70-74 лет (2,08 раза), минимальный - для домашних хозяйств, в которых представлены 50-54 летние (1,28 раза). При этом для этой группы (самой молодой) оба уровня доходов являются максимальными.

Анализ соотношения между работающими и не имеющими работу гражданами в различных возрастах (рис. 16) показывает ожидаемую динамику: наблюдается снижение доли работающих (с $3 / 4$ в возрасте 50-54 лет до уровня менее $1 \%$ в возрасте старше 80 лет) и зеркальный рост доли неработающих граждан (от 1/4 в возрасте 50-54 лет до почти 99 \% в возрасте 80 лет и старше). Социологи утверждают, что большинство людей в трудоспособном возрасте «... рассматривают ситуацию незанятости либо как личную трагедию, либо как временное явление, трудность, которую нужно преодолеть в самое ближайшее время» [30, с. 74]. Что же касается представителей более старших групп, то здесь по мере повышения возраста наблюдается постепенная адаптация к новому укладу жизни, сопровождаемая широчайшим разнообразием индивидуальных жизненных траекторий, не сводимых лишь к затуханию трудовой активности. Однако при этом не стоит сбрасывать со счетов и то, что многие пенсионеры оказываются на рынке труда вынуждено, по экономическим соображениям. Они просто не могут себе позволить «быть на 
пенсии»: для большинства «молодых» пенсионеров такой отдых отождествляется с недоступной роскошью.

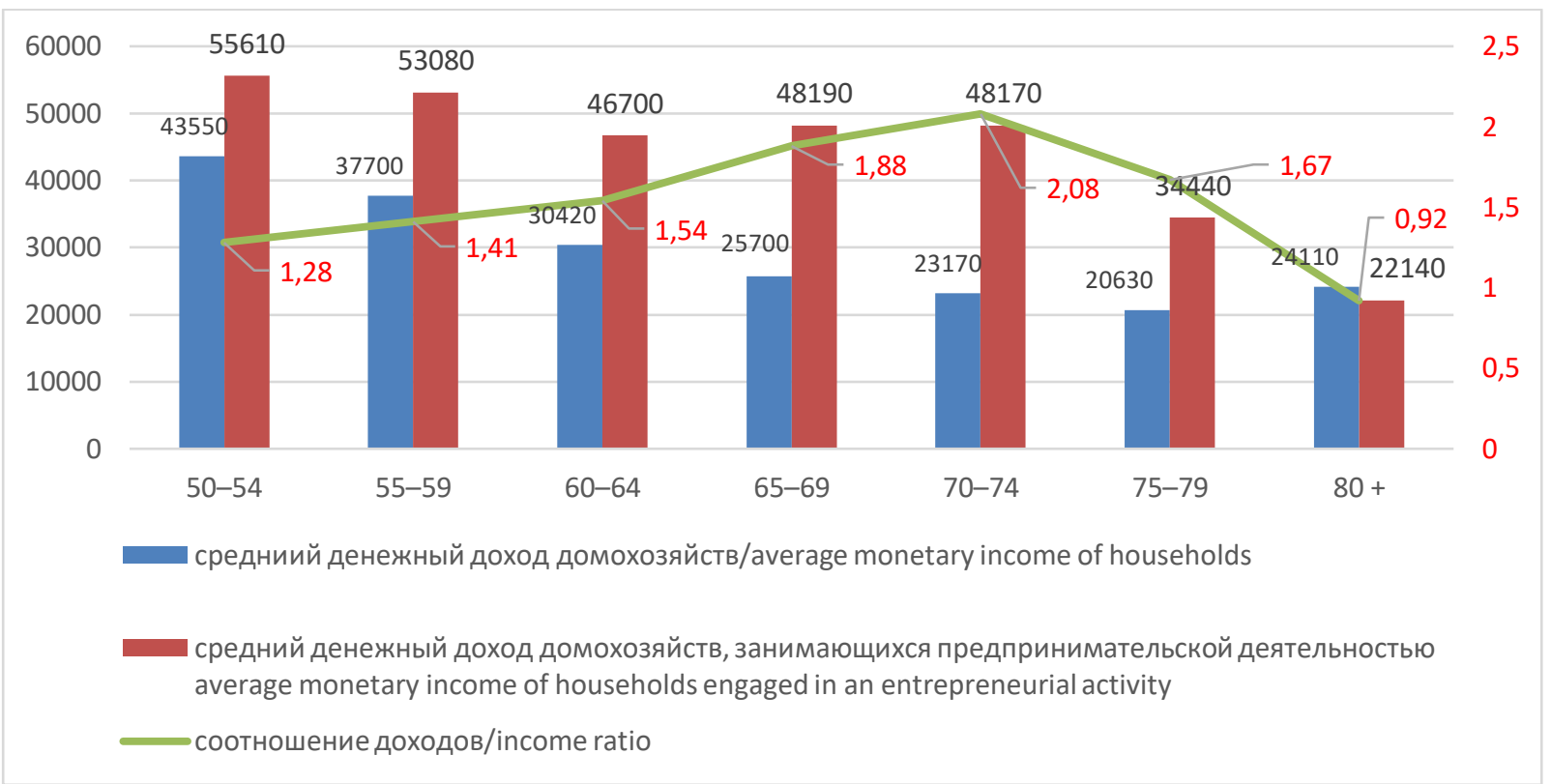

Pис. 15. Соотношение между средним денежным доходом домохозяйств и денежным доходом домохозяйств, занимающихся предпринимательской деятельностью, по возрастным группам (р/мес. после уплаты налогов, 2018 г.)

Fig. 15. Ratio between the average cash income of households and the cash income of households engaged in entrepreneurial activities by age group (rubles per month after taxes, 2018)

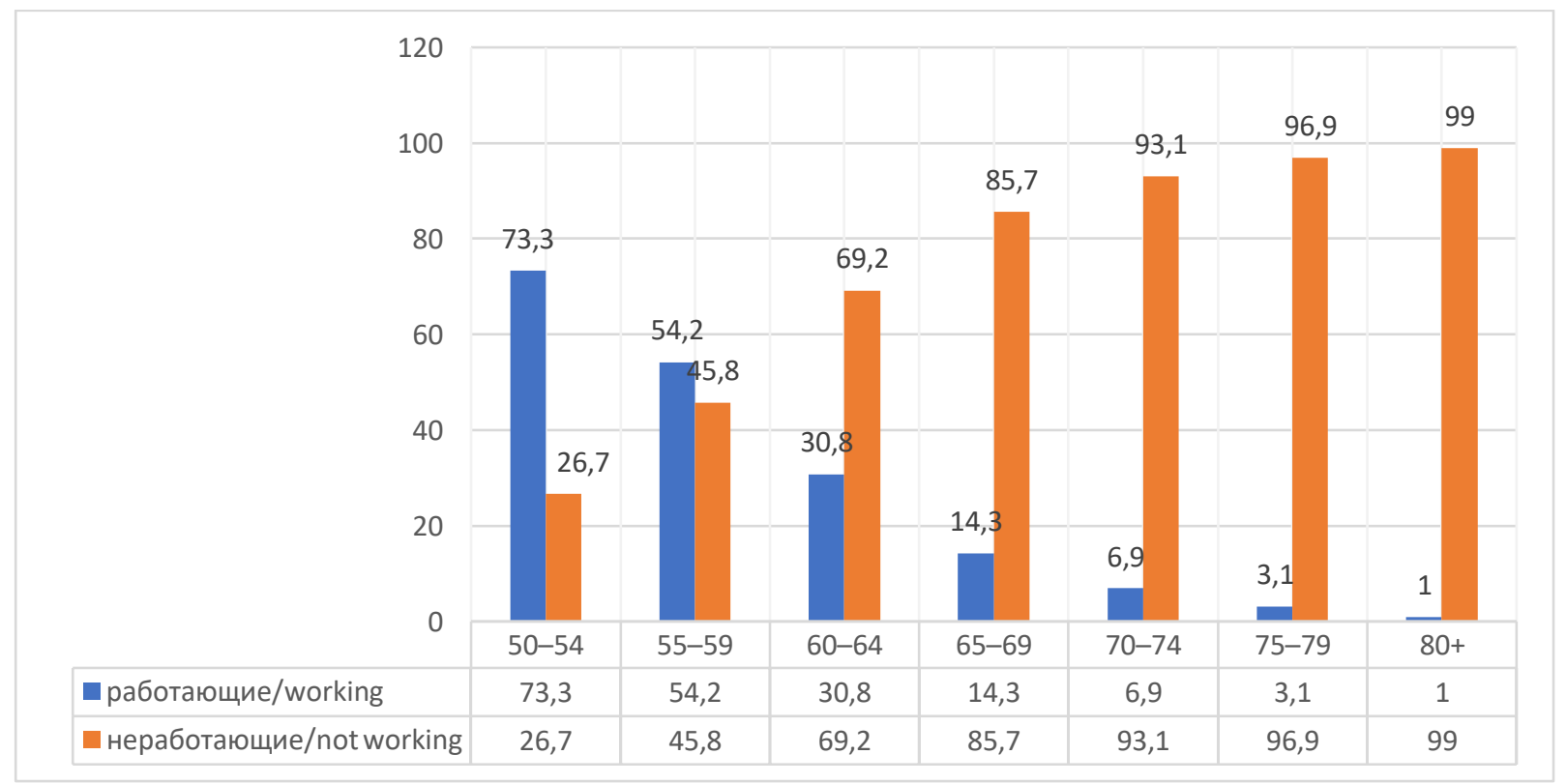

Рис. 16. Соотношение (в \%) между работающими и не имеющими работу гражданами в различных возрастных группах, 2018 г.

Fig. 16. Ratio (in \%) between employed and unemployed citizens in different age groups, 2018 
Отметим также весьма высокие и устойчивые к снижению по мере увеличения возраста оценки представителей различных возрастных групп себя как предпринимателей (рис. 17). Эти значения в каждом их трех периодов наблюдений несколько разнятся, но при этом у людей в возрасте 70 лет и старше они вполне сопоставимы с аналогичными ответами 50-летних респондентов. В числе прочего это может означать, что широко распространённый в массовом сознании образ пожилого человека как угнетенного и оторванного от жизни, как «человека советского», несущего на себе груз ушедшей эпохи, довольно плохо согласуется с действительностью и в значительной мере является стигмой.

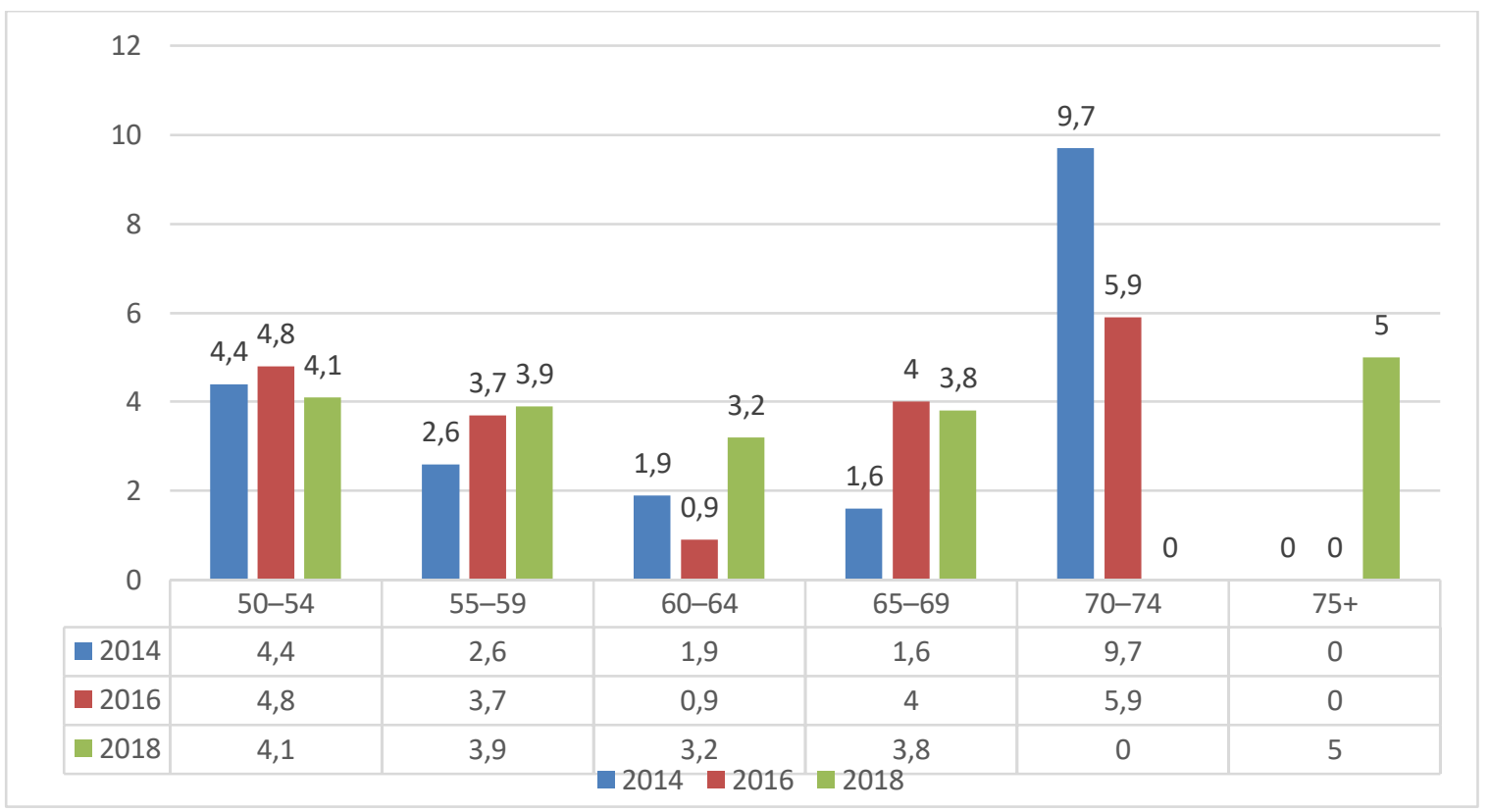

Puc. 17. Доля граждан (в \%) в каждой возрастной группе, заявивших о себе как о предпринимателях в 2014, 2016 и 2018 г2.

Fig. 17. Proportion of citizens (\%) in each age group, declared themselves as entrepreneurs, in 2014, 2016 and 2018

Полученные результаты позволяют сделать вывод о том, что распространенность предпринимательства в старшем возрасте имеет широкие перспективы для развития и в определенной мере связана с доступностью и потенциальной привлекательностью для пожилых людей рыночных ниш в так называемых «свободных» профессиях (допускающих самозанятость и не всегда требующих вложений в повышение или смену базовой квалификации): риэлтор, представитель в сетевом маркетинге, страховой агент, переводчик, репетитор, организатор праздников и др. Данные профессии, безусловно, требуют предпринимательского подхода, предполагают обладание навыками социальных взаимодействий, коммуникабельности, они имеют специфические фильтры на входе, но в целом они доступны для пенсионеров практически в той же степени, что и для граждан более молодого возраста.

\section{Траектория «Домашний труд и личное подсобное хозяйство»}

При анализе вовлеченности пожилых людей в региональный социум важным представляется изучение особенностей их активности, обусловленной владением и (или) пользованием земельными участками, в том числе извлечение из этого материальной 
выгоды и ее значимость в структуре доходов домашних хозяйств (рис. 18). Анализ ответов респондентов различных возрастных групп показал, что имеющийся у них земельный участок используется преимущественно для ведения личного подсобного хозяйства. Об этом заявили от 44,9 \% (минимум в возрастной группе 70-74 года) до 68 \% респондентов (максимум в возрастной группе 80 лет и старше). На втором по значимости месте находится использование земельного участка для сада и огорода: от 24 \% (минимум в возрастной группе 80 лет и старше) до 35,3 \% (максимум в возрастной группе 70-74 года). Наименее часто земельный участок используется как дача: от 7,9 \% (минимум в возрастной группе 80 лет и старше) до 21 \% (максимум в наиболее молодой из анализируемых групп, 50-54 года). Тем не менее даже в этой возрастной группе только каждый пятый опрошенный использует имеющийся земельный участок преимущественно как место отдыха, а не как еще одну сферу приложения своего труда и способ извлечения доходов от ЛПХ или для выращивания ягод, овощей и пр.

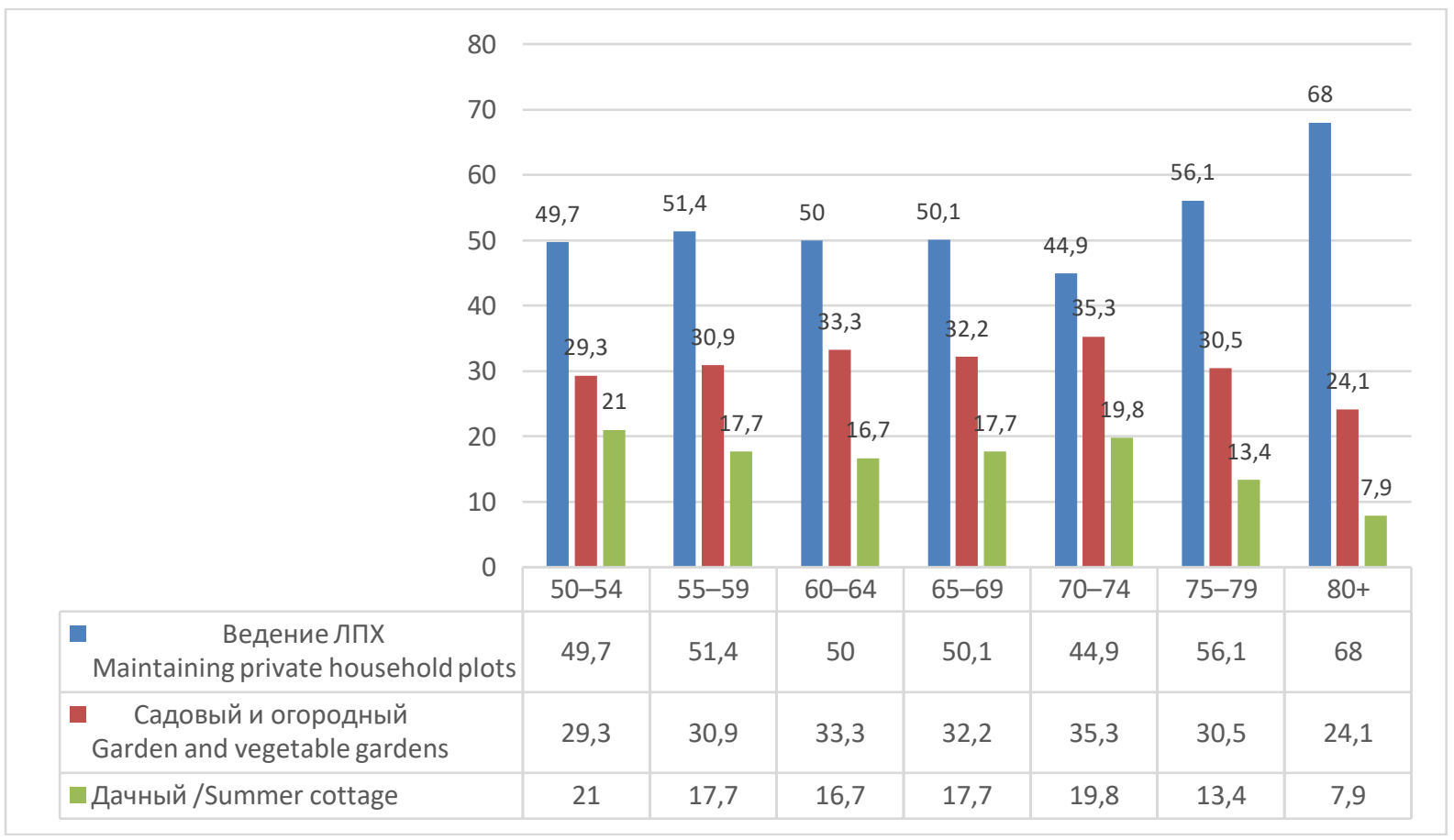

Puc. 18. Распределение ответов респондентов различных возрастных групп о назначении их земельного участка в 2018 г. (\%)

Fig. 18. Distribution of answers of respondents of different age groups about the purpose of their land plot (\%), 2018

Сделанный вывод о преимущественно прагматическом подходе к имеющемуся земельном участку подтверждают также ответы респондентов различных возрастных групп, показавшие, что в качестве источника средств к существованию во многих домохозяйствах в 2018 г. были доходы от продажи продукции личного подсобного хозяйства, собранных грибов, ягод, продуктов охоты и рыболовства (рис. 19). В наибольшей степени это оказалось характерным для граждан 55-59 лет (здесь это подтвердил каждый четвертый опрошенный), в наименьшей степени заявили о таком источнике средств к существованию наиболее пожилые люди (4,5 \% опрошенных). Весьма высока эта доля и у наиболее молодых граждан - 21,5 \% для респондентов 50-54 лет, а также у граждан 60-64 и 65-69 лет - около 18\%. 


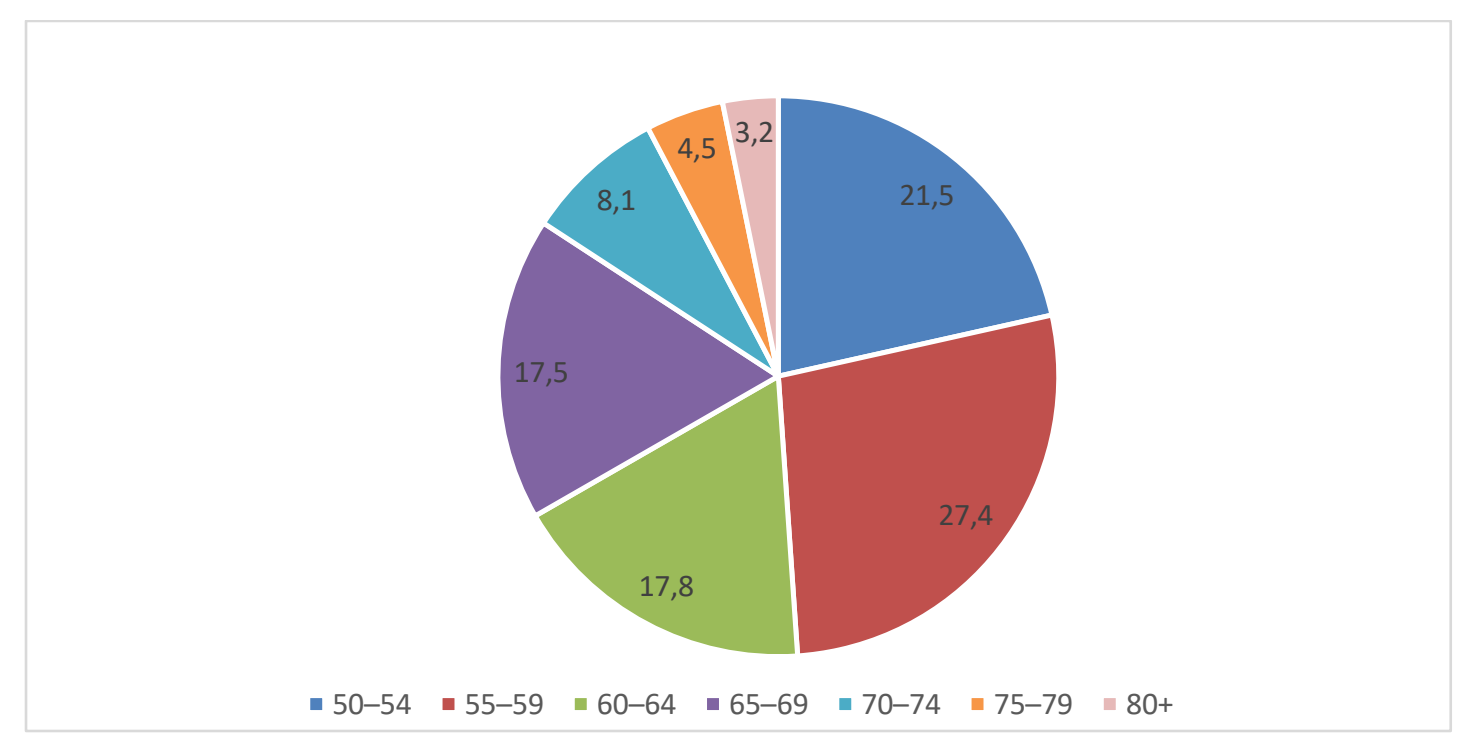

Puc. 19. Доля респондентов различных возрастных групп, подтвердивших, что в качестве источников средств к существованию в их домохозяйствах в 2018 г. были доходы от продажи продукции личного подсобного хозяйства, собранных грибов, ягод, продуктов охоты и рыболовства

Fig. 19. Share of respondents of different age groups who reported that the income from the sale of products of personal subsidiary plots, collected mushrooms, berries, hunting and fishing products was the source of livelihood in their households in 2018

Желание и готовность трудиться в ЛПХ, возделывать огород, продавать грибы, ягоды, продукты охоты и рыболовства не противоречат ответам респондентов о наличии у них дополнительной работы. Можно предположить, что на фоне весьма невысокого уровня доходов от основной работы, заметная часть опрошенных различных возрастов пытаются компенсировать нехватку средств к существованию не только работой в ЛПХ и прочими перечисленными выше приносящими доход активностями, но и за счет вторичной занятости. Так, в возрасте 50-54 лет не менее $8 \%$ опрошенных подтвердили наличие дополнительной работы в каждом из трех периодов наблюдений. По мере увеличения возраста респондентов вторичная занятость в основном снижается, при этом в возрасте 65-69 и 70-74 лет она имеет примерно равные по годам значения, с динамикой к снижению в 2018 г. Снижение вторичной занятости в 2018 г. характерно для всех анализируемых возрастных групп, за исключением наиболее молодых респондентов: здесь, в отличие от других возрастных групп, доля ответов о вторичной занятости за все три периода наблюдений практически не изменилась.

Доходы, полученные от продажи с огородов (рис. 20), оказываются весьма значимыми и примерно равными для представителей практически всех анализируемых возрастных групп. Об этом заявили в среднем 5-6 \% граждан в широком диапазоне возраста (от 50 до 74 лет). Доля людей, подтвердивших получение таких доходов, снижется примерно вдвое к возрасту 75-79 лет и становится ничтожной для граждан старше 80 лет (1$2 \%)$.

Не наблюдается какой-то явной динамики и при анализе распределения ответов респондентов различных возрастных групп, получавших доходы от сдачи собственности в аренду. Таких людей в целом очень мало (максимум - 1,6 \% опрошенных в возрасте 50-54 лет в 2016 и 2018 гг.). Полученные данные снижаются (сходят на нет) по мере повышения возраста респондентов и незначительно меняются по годам наблюдения. 


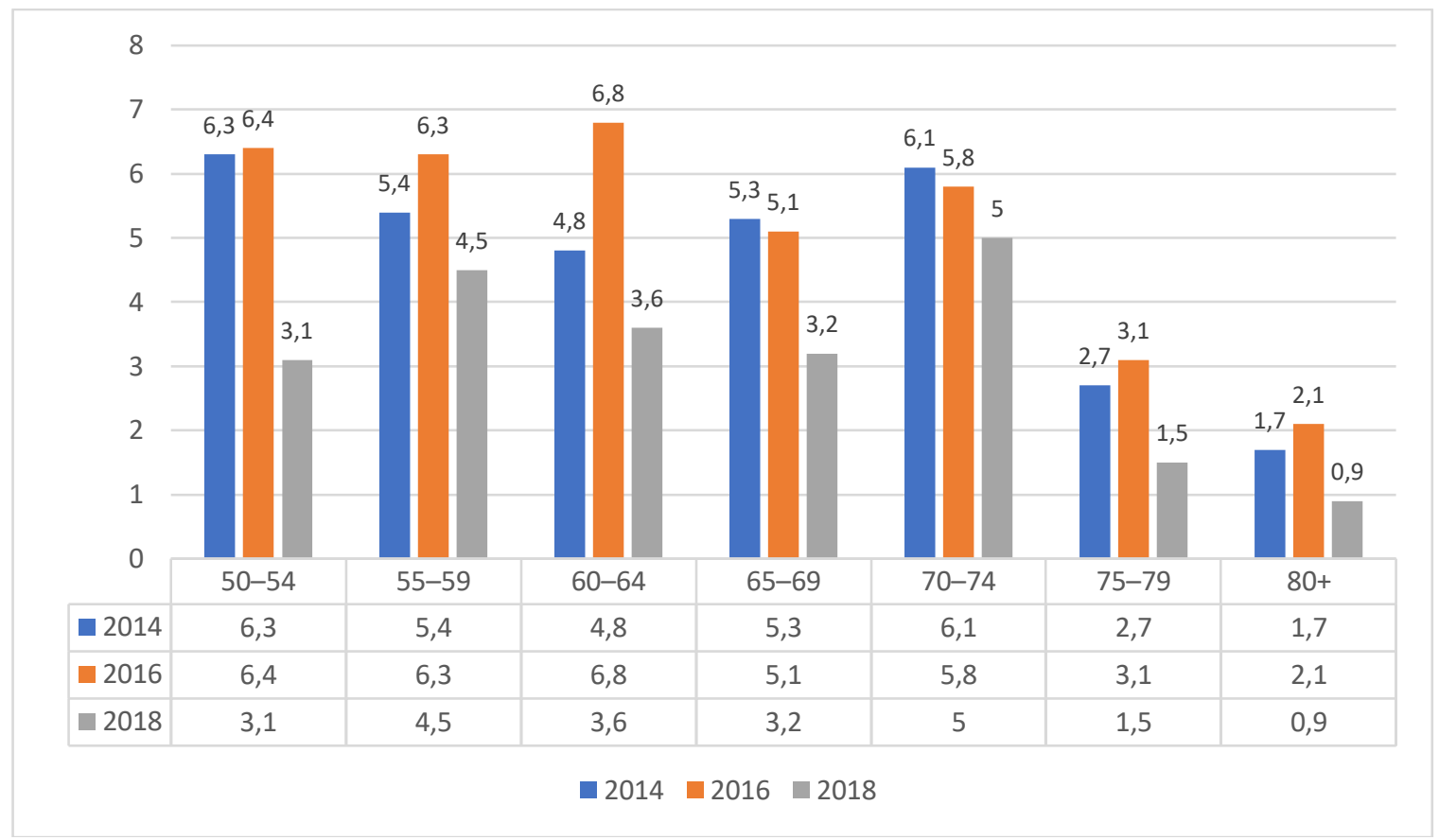

Puс. 20. Распределение (в \%) респондентов различных возрастных групп, получавших доходы от продажи с огородов

Fig. 20. Distribution (in \%) of respondents of different age groups who received income from sales from vegetable gardens

При сравнении структуры источников дополнительных доходов респондентов различных возрастных групп подчеркнем сделанный ранее вывод о превалировании в нем продаж с огородов, причем доля этого источника доходов растет по мере повышения возраста респондентов. Так, на его долю в 2014 г. приходится от 41,3 \% дополнительных доходов у граждан 50-54 лет (минимум) до 69,2\% у граждан 80 лет и старше (максимум). Вторыми по значимости в 2014 г. ожидаемо были доходы от продажи живности. При этом если у относительно молодых респондентов (50-54 и 55-59 лет) они примерно также значимы, как и доходы от продаж с огородов, то по мере повышения возраста респондентов их значимость падает в 2-3 раза (на фоне одновременного роста у более пожилых людей доходов от продаж с огородов). На третьем месте по значимости в структуре доходов во всех возрастах группах в 2014 г. оказываются доходы от продажи дикоросов, на последнем - доходы от сдачи в аренду недвижимости.

Что касается аналогичных данных за 2018 г. (рис. 21), то здесь обращает на себя внимание увеличение значимости доходов от продажи живности у самых молодых респондентов: для граждан 50-54 лет этот источник дополнительных доходов оказался наиболее важным (41,7\%), на втором месте - продажи с огородов $(27,8 \%)$, на третье продажи дикоросов (16,5 \%), а на четвертом - с небольшим отрывом - доходы от аренды $(13,9 \%)$. У граждан 55-59 лет примерно в равной степени ценными являются доходы от продажи с огородов и продажи живности (42,1 \% и 39,7 \% соответственно), доходы от продажи дикоросов и сдачи имущества в аренду для них менее значимы почти в 4 раза (9,5 и 8,7 \%). Для граждан 60-64 лет распределение источников дополнительных доходов аналогично ситуации предшествующих лет, при этом у них заметно увеличение доли доходов от сдачи имущества в аренду $(8,1 \%)$. Интересно выглядит распределение источников дохода у граждан 65-69 лет. В ней на третьем месте после доходов от продаж с огородов (61 \%) и оказались доходы от продажи дикоросов $(20,8 \%)$, которые 
превысили долю доходов от продажи живности (13\%). Для возрастной группы 70-74 года обращает на себя внимание то, что здесь на третью позицию вышли доходы от аренды (10,4 \%). Также этот источник доходов оказывается в 2018 г. весьма существенным и у граждан самой старшей возрастной группы (80 лет и старше): он занимает 11,8 $\%$ от общей суммы дополнительных доходов. Стоит отметить, что поскольку данные по данному индикатору рассчитываются как доля от ответивших в каждой возрастной группе, то в перспективе здесь целесообразно анализировать структуру ответов и тенденции их изменений.

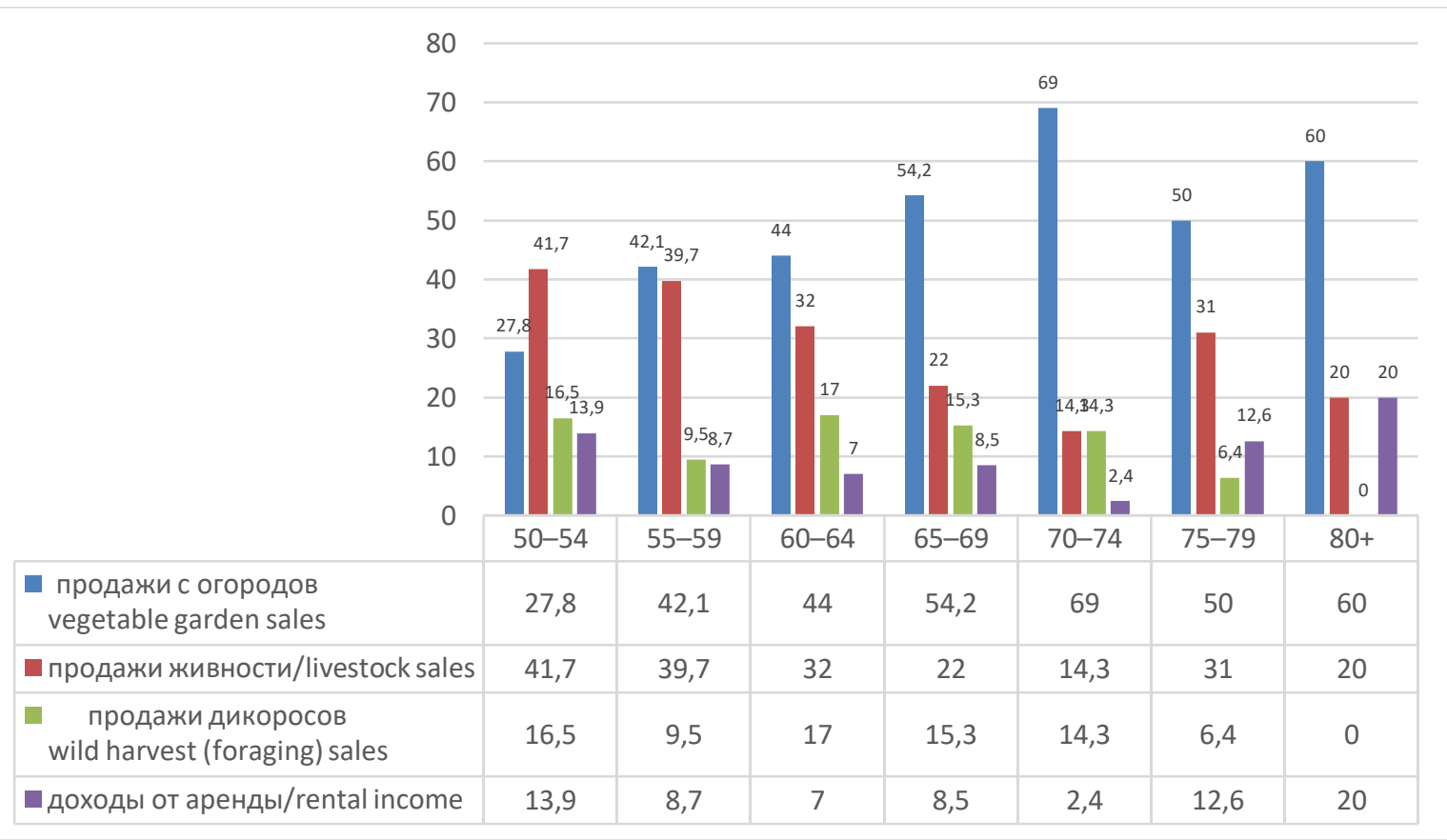

Puc. 21. Структура источников дополнительных доходов респондентов различных возрастных групп в 2018 г., \% ответивших соответствующей возрастной группы

Fig. 21. Structure of sources of additional income of respondents of different age groups in 2018, \% of respondents in the corresponding age group

Таким образом, весьма активное участие многих граждан старших возрастов в использовании своих земельных участков в качестве источников дополнительного дохода, выращивание на них овощей, фруктов и ягод, разведение живности, как и вторичная занятость, являются попытками запуска компенсаторных механизмов для решения острой проблемы низких доходов (как зарплат, так и пенсий). При этом, как показал анализ, дополнительные доходы от ЛПХ, продажи с огородов и пр. принципиально этой проблемы не решают. Доходы от собственности (при их положительной динамике у граждан старших возрастных групп) пока остаются крайне незначительными в общей сумме доходов населения и вынуждают пожилых граждан максимально прагматично подходить к использованию имеющегося у них земельного участка как источника гарантированного (хотя и весьма небольшого) дополнительного дохода, а также стремиться максимизировать продажи продукции, выращенной в личном подсобном хозяйстве, доходы от продажи собранных грибов, ягод, продуктов охоты и рыболовства. 


\section{Заключение}

Анализ показал широкое разнообразие траекторий вовлеченности граждан различных возрастных групп (в том числе за границами трудоспособного возраста) в трудовую активность, что в целом отражает их высокую адаптивность к социально-экономическим условиям РФ последних десятилетий. При этом обращает на себя внимание следующее:

1) потенциал трудовой активности российских граждан в различных возрастных группах является довольно высоким и при переходе от относительно молодых к более старшим возрастным группам меняется преимущественно структура видов занятости, чем ее общий уровень, при этом значительная часть трудового потенциала работников более старшего возраста задействована (по их субъективному мнению) не в полной мере;

2) во всех возрастных группах весьма высока доля респондентов, отмечающих множественную занятость, в том числе в предпринимательстве, в частности по мере повышения возраста растет доля тех, кто получает дополнительные доходы от ЛПХ;

3) довольно высокими являются оценки удовлетворённости граждан различными аспектами своей трудовой деятельности (в том числе у граждан за пределами трудоспособного возраста);

4) на фоне выявленных тенденции обеспокоенность вызывают весьма низкие оценки удовлетворённости граждан в различных возрастных группах заработной платой, доходами семей и их динамикой в последние годы. Возможно, что здесь мы имеем дело с негативным влиянием социально-экономических факторов макрооокружения и довольно низким (по сравнению с гражданами аналогичных возрастных групп в развитых странах) потенциалом здоровья.

Таким образом, для успешной реализации научной идеи о потенциальной множественности успешных траекторий вовлеченности пожилых людей в региональный социум, возможности развития таких траекторий и корректной оценки их эффективности (с точки зрения интересов личности, работодателя и общества) требуется:

- во-первых, анализ лучших практик (отечественных и зарубежных) эффективного комбинирования ресурсного потенциала различных поколений (в том числе на рынке труда), компетенций личности и возможностей социума для достижения устойчивой автономии пожилых людей, корпоративной и региональной социально-экономической динамики;

- во-вторых, разработка методики, позволяющей корректно оценивать эффективность различных траекторий вовлеченности пожилых людей в региональный социум для различных субъектов (индивида, работодателя, общества). Предполагается, что в основании методики будет система показателей, включающая как объективные (количественные) индикаторы, так и субъективные (качественные, экспертные) оценки эффективности участия пожилых людей в региональном социуме по широкому спектру мониторинговых параметров, учитывающих специфические для конкретного региона особенности рынка труда, социокультурные и институциональные факторы;

- в-третьих, проектирование и апробация адекватных для определенного социума траекторий вовлеченности граждан старшего поколения, по результатам которой планируется разработка практических рекомендаций для органов региональной власти, нацеленных на актуализацию региональных социально-экономических программ в интересах людей старшего возраста и модернизации институтов социальной сферы;

- в-четвертых, разработка комплексной модели социально-экономической интеграции, позволяющей обнаружить противоречия между потенциалом социально-экономических ролей лиц третьего возраста и фактической реализацией при формировании долгосрочной социальной политики государства. 
Исследование выполнено по проекту РФФИ «Разработка комплексной оценки эффективности вовлеченности пожилых людей в региональный социум», № 19-010-00984.

\section{СПИСОК ЛИТЕРАТУРЫ}

1. Стратегия действий в интересах граждан старшего поколения в Российской Федерации до 2025 года: распоряжение Правительства РФ от 05.02.2016 № 164-p. URL: https://mintrud.gov.ru/ministry/programms/37/2 (дата обращения 14.10.2020).

2. Cumming E., Henry W.E., Damianopoulos E. A formal statement of disengagement theory // Growing old: the process of disengagement. - New York: Basic Books, 1961. - P. 210-218.

3. Lucas R.E. (Jr) On the mechanics of economic development // Journal of monetary economics. - 1988. V. 22. - № 1. - P. 3-42.

4. Schultz T.W. Education and economic growth // Social Forces Influencing American Education. - Chicago: Chicago University of Chicago Press, 1961. - 252 p.

5. Nafukho F.M., Hairston N., Brooks K. Human capital theory: Implications for human resource development // Human Resource Development International. - 2004. - V. 7. - № 4. - P. 545-551.

6. McLean G.N., Bartlett K.R., Cho E. Human resource development as national policy: Republic of Korea and New Zealand // Pacific-Asian Education Journal. - 2003. - V. 15. - P. 41-59.

7. McGlynn C. EC legislation prohibiting age discrimination: «Towards a Europe for All Ages»? // Cambridge Yearbook of European Legal Studies. - 2000. - V. 3. - P. 279-299.

8. Gauthier A.H., Smeeding T.M. Time use at older ages: cross-national differences // Research on Aging. 2003. - V. 25. - № 3. - P. 247-274.

9. Clarke A., Warren L. Hopes, fears and expectations about the future: what do older people's stories tell us about active ageing? // Ageing \& Society. - 2007. - V. 27. - № 4. - P. 465-488.

10. Ranzijn R. Active ageing - another way to oppress marginalized and disadvantaged elders? Aboriginal elders as a case study // Journal of Health Psychology. - 2010. - V. 15. - № 5. - P. 716-723.

11. Dey P., Steyaert C. Myth in social entrepreneurship research: an inquiry into rationalist, ideological and dialectic practices of demystification // Social Entrepreneurship. 2018. URL: https://www.researchgate.net/publication/323958719_Myth_in_social_entrepreneurship_research_an_inquir y_into_rationalist_ideological_and_dialectic_practices_of_demystification (дата обращения 30.08.2020).

12. Carstairs S., Keon W. J. Issues and options for an aging population: special senate committee on aging second interim report. - Ottawa: Special Senate Committee on Aging, 2008. - 76 p. URL: https://sencanada.ca/content/sen/Committee/392/agei/rep/repfinmar08-e.pdf (дата обращения: 20.10.2020).

13. Sidorenko A., Zaidi A. Active ageing in CIS countries: semantics, challenges, and responses // Current Gerontology and Geriatrics Research. - 2013. - V. 2013. URL: https://doi.org/10.1155/2013/261819 (дата обращения 30.08.2020).

14. Varlamova M., Ermolina A., Sinyavskaya O. Active ageing index as an evidence base for developing a comprehensive active ageing policy in Russia // Journal of Population Ageing. - 2017. - V. 10. - № 1. - P. 4171.

15. Darin-Mattsson A., Fors S., Kåreholt I. Different indicators of socioeconomic status and their relative importance as determinants of health in old age // International journal for equity in health. -2017 . - V. 16. - № 1. - P. $1-11$.

16. Iwamasa G.Y., Iwasaki M. A new multidimensional model of successful aging: Perceptions of Japanese American older adults // Journal of cross-cultural gerontology. - 2011. - V. 26. - № 3. - P. 261-278.

17. Пожилые в современной России: между занятостью, образованием и здоровьем / И.А. Григорьева, Л.А. Видясова, А.В. Дмитриева, О.В. Сергеева. - СПб.: Алетейя, 2015. - 336 с.

18. Adjustment to retirement: a cross-national study / R.J. Havighurst, J.M. Munnichs, B.L. Neugarten, H. Thomae. - Assen: Royal Vangorcum Ltd., 1969. - 195 p.

19. Hedge J.W., Borman W.C., Lammlein S.E. The aging workforce: realities, myths, and implications for organizations. - Washington, DC: American Psychological Association, 2006. - 203 p. URL: https://doi.org/10.1037/11325-000 (дата обращения 30.08.2020).

20. A scoping review of the incentives for a prolonged work life after pensionable age and the importance of «bridge employment» / A.B. Carlstedt, G. Brushammr, C. Bjursell, P. Nystedt, G. Nilsson // Work. - 2018. V. 60. - № 2. - P. 175-189.

21. Beutell N.J., Schneer J.A. Working beyond retirement: are there gender differences in bridge employment? // Ageing International. URL: https://link.springer.com/article/10.1007/s12126-020-09363-0\#citeas (дата обращения 30.08.2020). 
22. Mazumdar B., Warren A.M., Brown T. C. Bridge employment: understanding the expectations and experiences of bridge employees // Human Resource Management Journal. - 2020. URL: https://doi.org/10.1111/1748-8583.12323 (дата обращения 30.08.2020).

23. Стратегия-2020: Новая модель роста - новая социальная политика. Книга 1 / под научн. ред. В.А. Мау, Я.И. Кузьминова. - М.: Издательский дом «Дело» РАНХиГС, 2013. - 430 с.

24. Комплексное наблюдение условий жизни населения, КОУЖ-2018. Федеральная служба государственной статистики (Росстат). URL: https://rosstat.gov.ru/free_doc/new_site/KOUZ18/index.html (дата обращения 30.08.2020).

25. Understanding the thoughts, feelings and behaviors of people around the world. Gallup World Poll. URL: https://www.gallup.com/analytics/318875/global-research.aspx (дата обращения 10.09.2020).

26. Волчкова Н., Крюков В., Казаков В. Будущее российской экономики. - Москва: Эксмо, 2020. - 240 с.

27. Программа «Навыки мудрых». Федеральный проект «Старшее поколение» национального проекта «Демография». Министерство труда и социальной защиты Российской Федерации, Федеральная служба по труду и занятости (Роструд). Ворлдскиллс Россия. URL: https://50plus.worldskills.ru/ (дата обращения 03.11.2020).

28. Как меняется в России «теневая» занятость? // Фактограф. URL: https://www.factograph.info/ a/29190006.html (дата обращения 17.10.2020).

29. Гальчева А. Росстат сообщил о росте неформальной занятости в России. URL: https://www.rbc.ru/economics/05/09/2019/5d6e74fb9a794709eeba4f8c (дата обращения 17.10.2020).

30. Рогозин Д.М. Либерализация старения, или труд, знания и здоровье в старшем возрасте // Социологический журнал. - 2012. - № 4. - С. 62-93.

31. Григорьева И.А. Смена парадигмы в понимании старения // Журнал исследований социальной политики. - 2018. - Т. 16. - № 1. - С. 5-6.

Поступила 19.11.2020 2. 


\title{
COMPREHENSIVE ASSESSMENT OF SOCIO-ECONOMIC INVOLVEMENT OF OLDER GENERATION IN THE REGIONAL SOCIETY ON THE EXAMPLE OF LABOR ACTIVITY
}

\author{
Irina A. Pavlova ${ }^{1,2}$, \\ iapav@mail.ru \\ Olga P. Nedospasova ${ }^{1,3}$, \\ olgaeconomy@mail.ru \\ Galina A. Barysheva1, \\ ganb@tpu.ru \\ ${ }^{1}$ National Research Tomsk Polytechnic University, \\ 30, Lenin avenue, Tomsk, 634050, Russia \\ 2 Tomsk State University of Control Systems and Radioelectronics, \\ 40, Lenin avenue, Tomsk, 634050, Russia \\ ${ }^{3}$ National Research Tomsk State University, \\ 36, Lenin avenue, Tomsk, 634050, Russia
}

Irina A. Pavlova, Cand. Sc., associate professor, National Research Tomsk Polytechnic University; associate professor, Tomsk State University of Control Systems and Radioelectronics.

Olga P. Nedospasova, Dr. Sc., professor, National Research Tomsk Polytechnic University; professor, National Research Tomsk State University.

Galina A. Barysheva, Dr. Sc., professor, National Research Tomsk Polytechnic University.

Relevance. With age, a person has a growing deficit of socio-economic roles, the spectrum narrows when choosing worthy trajectories of socio-economic activity. In this regard, the study of various trajectories of involvement in the regional society becomes relevant. First of all, such trajectories are associated with labor activity, which is realized through the institutions of hired labor, entrepreneurship and work in the household. The goal of this study is a comprehensive analysis of the socio-economic activity of older citizens on the example of several trajectories of labor activity. This article is also intended to present the results of assessing the trajectories of labor activity for older people at different stages of their life trajectory. Methods: descriptive statistical analysis based on microdata from two longitudinal surveys: "Russian Longitudinal Monitoring Survey» of the Higher School of Economics; "Comprehensive Monitoring of Living Conditions of the Population», conducted by Rosstat. The analysis results are presented in the context of age groups (50-54, 55-59, 60-64, 65-69, 70-74, 75-80, 80+) along three trajectories: (1) employment for hire (full and part-time); (2) self-employment and entrepreneurship; (3) domestic work and personal subsidiary farming. Conclusions. The analysis showed a wide variety of trajectories for the involvement of citizens of different age groups (including those beyond the working age) in labor activity, which in general reflects their high adaptability to the socioeconomic conditions of recent decades.

Key words: Elderly people, older generation, socio-economic activity, involvement, labor activity, employment, personal subsidiary farming, regional society, labor market.

The research was carried out by the project of the RFBR «Development of complex assessment of efficiency of elderly people involvement into regional society», no. 19-010-00984. 


\section{REFERENCES}

1. Strategiya deystviy $v$ interesakh grazhdan starshego pokoleniya $v$ Rossiyskoy Federatsii do 2025 [Strategy if actions in the interest of older generation in the Russian Federation till 2025]. Rasporyazhenie Pravitelstva RF ot 05.02.2016 no. 164-p [Government Decree of the RF from February 5, 2016 N 164-p]. Available at: https://mintrud.gov.ru/ministry/programms/37/2 (accessed 14 October 2020).

2. Cumming E., Henry W.E., Damianopoulos E. A formal statement of disengagement theory. Growing old: the process of disengagement. New York, Basic Books, 1961. pp. 210-218.

3. Lucas R.E. (Jr). On the mechanics of economic development. Journal of monetary economics, 1988, vol. 22, no. 1, pp. 3-42.

4. Schultz T.W. Education and economic growth. Social Forces Influencing American Education. Ed. by N.B. Henry. Chicago, Chicago University of Chicago Press, 1961. 252 p.

5. Nafukho F.M., Hairston N., Brooks K. Human capital theory: implications for human resource development. Human Resource Development International, 2004, vol. 7, no. 4, pp. 545-551.

6. McLean G.N., Bartlett K.R., Cho E. Human resource development as national policy: Republic of Korea and New Zealand. Pacific-Asian Education Journal, 2003, v.15, pp. 41-59.

7. McGlynn C. EC Legislation prohibiting age discrimination: «Towards a Europe for All Ages»? Cambridge Yearbook of European Legal Studies, 2000, vol. 3, pp. 279-299.

8. Gauthier A.H., Smeeding T.M. Time use at older ages: cross-national differences. Research on Aging, 2003, vol. 25, no. 3, pp. 247-274.

9. Clarke A., Warren L. Hopes, fears and expectations about the future: what do older people's stories tell us about active ageing? Ageing \& Society, 2007, vol. 27, no. 4, pp. 465-488.

10. Ranzijn R. Active ageing - another way to oppress marginalized and disadvantaged elders? Aboriginal elders as a case study. Journal of Health Psychology, 2010, vol. 15, no. 5, pp. 716-723.

11. Dey P., Steyaert C. Myth in social entrepreneurship research: an inquiry into rationalist, ideological and dialectic practices of demystification. Social Entrepreneurship. 2018. Available at: https://www.researchgate.net/publication/323958719_Myth_in_social_entrepreneurship_research_an_inquiry_into_rationalist_ideological_and_dialectic_practices_of_demystification (accessed 30 August 2020).

12. Carstairs S., Keon W.J. Issues and options for an aging population: special senate committee on aging second interim report. Ottawa, Special Senate Committee on Aging, 2008. 76 p. Available at: https://sencanada.ca/content/sen/Committee/392/agei/rep/repfinmar08-e.pdf (accessed 20 October 2020).

13. Sidorenko A., Zaidi A. Active ageing in CIS countries: semantics, challenges, and responses. Current Gerontology and Geriatrics Research, 2013, vol. 2013. Available at: https://doi.org/10.1155/2013/261819 (accessed 30 August 2020).

14. Varlamova M., Ermolina A., Sinyavskaya O. Active ageing index as an evidence base for developing a comprehensive active ageing policy in Russia. Journal of Population Ageing, 2017, vol. 10, no. 1, pp. 41-71.

15. Darin-Mattsson A., Fors S., Kåreholt I. Different indicators of socioeconomic status and their relative importance as determinants of health in old age. International journal for equity in health, 2017, vol. 16, no. 1, pp. $1-11$.

16. Iwamasa G.Y., Iwasaki M. A new multidimensional model of successful aging: Perceptions of Japanese American older adults. Journal of cross-cultural gerontology, 2011, vol. 26, no. 3, pp. 261-278.

17. Grigoreva I.A., Vidyasova L.A., Dmitrieva A.V., Sergeeva O.V. Pozhilye v sovremennoy Rossii: mezhdu zanaytostyu, obrazovaniem i zdoroviem [Old persons in today's Russia: between employment, education and health]. St. Petersburg, Aleteya Publ., 2015. 336 p.

18. Havighurst R.J., Munnichs J.M., Neugarten B.L., Thomae H. Adjustment to retirement: a cross-national study. Assen, Royal Vangorcum Ltd., 1969. 195 p.

19. Hedge J.W., Borman W.C., Lammlein S.E. The aging workforce: realities, myths, and implications for organizations. Washington, DC, American Psychological Association, 2006. 203 p. Available at: https://doi.org/10.1037/11325-000 (accessed 30 August 2020).

20. Carlstedt A.B., Brushammr G., Bjursell C., Nystedt P., Nilsson G. A scoping review of the incentives for a prolonged work life after pensionable age and the importance of «bridge employment». Work, 2018, vol. 60, no. 2, pp. 175-189.

21. Beutell N.J., Schneer J.A. Working beyond retirement: are there gender differences in bridge employment? Ageing International. Available at: https://link.springer.com/article/10.1007/s12126-020-09363-0\#citeas (accessed 30 August 2020).

22. Mazumdar B., Warren A.M., Brown T.C. Bridge employment: understanding the expectations and experiences of bridge employees. Human Resource Management Journal, 2020. Available at: https://doi.org/10.1111/1748-8583.12323 (accessed 30 August 2020). 
23. Strategiya-2020: Novaya model rosta - novaya sotsialnaya politika. Kniga 1 [Strategy-2020: New model of growth - new social policy. Part 1]. Eds. V.A. Mau, Ya.I. Kuzminov. Moscow, Publishing house «Delo» RANKhiGS, 2013. 430 p.

24. Kompleksnoe nabludenie usloviy zhizni naseleniya, KOUZh-2018 [Comprehensive monitoring of living conditions]. Federal State Statistics Service (Rosstat). Available at: https://rosstat.gov.ru/free_doc/new_site/KOUZ18/index.html (accessed 30 August 2020).

25. Understanding the thoughts, feelings and behaviors of people around the world. Gallup World Poll. Available at: https://www.gallup.com/analytics/318875/global-research.aspx (accessed 10 September 2020).

26. Volchkova N., Kryukov V., Kazakov V. Budushchee rossiyskoy ekonomiki [Future of Russian economy]. Moscow, Eksmo Publ., 2020. 240 p.

27. Programma «Navyki mudrykh». Federalniy proekt «Starshee pokolenie» natssionalnogo proekta «Demographiya» [Program «Skills of the wise». Federal project «Older generation» of the national project «Demography»]. Ministry of labor and social protection of the Russian Federation, Federal department of labor and employment (Rostrud). Worldskills Russia. Available at: https://50plus.worldskills.ru/ (accessed 3 November 2020).

28. Kak menyaetsya v Rossii «tenevaya» zanaytost? [How that «shadow» employment is changing in Russia?]. Faktograf. Available at: https://www.factograph.info/a/29190006.html (accessed 17 October 2020).

29. Galcheva A. Rosstat soobshchil o roste neformalnoy zanyatosti [Rosstat announced the rise of informal employment]. Available at: https://www.rbc.ru/economics/05/09/2019/5d6e74fb9a794709eeba4f8c (accessed 17 October 2020).

30. Rogozin D.M. Liberalizatsiya stareniya, ili trud, znaniya i zdorovye v starshem vozraste [Ageing liberalization, or employment, knowledge and health in old age]. Sociological journal, 2012, no. 4, pp. 62-93.

31. Grigoryeva I.A. Smena paradigmy v ponimanii stareniya [Paradignm changes in understanding ageing]. Journal of social policy studies, 2018, vol. 16, no. 1, pp. 5-6.

Received: 19 November 2020. 